\title{
A NEW POSTCLASSIC CHRONOLOGY FOR YAUTEPEC, MORELOS
}

Timothy S. Hare and Michael E. Smith

Department of Anthropology, State University of New York, Albany, NY 12222, USA

\begin{abstract}
We describe the derivation of a new archaeological chronology for the Postclassic period at Yautepec, Morelos. We first apply cluster analysis to ceramic type frequencies for 47 excavated contexts to identify groups of related ceramic collections. This classification is then extended to several hundred additional collections using discriminant-function analysis. The groups are evaluated successfully against stratigraphy and radiocarbon dates, resulting in their designation as chronological phases.

Radiocarbon determinations are then used to assign calendar dates to the phases. The new chronology consists of one Middle Postclassic phase (Pochtla), two Late Postclassic phases (Atlan, Molotla), and one Early Colonial phase (Santiago). We also explore issues concerning the extension of this chronology to other Postclassic sites in the Yautepec Valley.
\end{abstract}

The past two decades have seen a tremendous growth of research on Aztec society by archaeologists and ethnohistorians. As a result, scholars are now addressing a variety of issues at a level of detail unheard of only 20 years ago. A few examples include household and family organization, social classes, women's roles, domestic ritual, craft specialization, agricultural intensification, the expansion of the Triple Alliance empire, and the nature of citystate organization (e.g., Lockhart 1992; Smith 1996; and articles in Hodge and Smith [1994] and Santley and Hirth [1993]). One of the major advantages of archaeological data on these topics, compared to ethnohistoric data, is the diachronic perspective it affords. Archaeologists can not only describe Aztec society at the time of the Spanish Conquest, but we can also study the processes of change that created Aztec society and culture as observed in 1519.

Many of these processes of change operated at a relatively rapid pace. At the time of the fall of Tula in the twelfth century A.D., central Mexico was a thinly populated rural backwater with few large cities or extensive states (Sanders et al. 1979:137-153). The arrival of the Nahuatl-speaking Aztlan peoples led to processes of demographic, economic, and political expansion during the Middle Postclassic period (A.D. 1150-1350). Processes of change accelerated in subsequent Late Postclassic times (A.D. 1350-1520). The formation of the Triple Alliance empire in 1428 marked a major turning point in Aztec history, and the expansion of the empire had far-reaching effects on Aztec society in both the Basin of Mexico and the surrounding central Mexican valleys (Berdan et al. 1996). Most ethnohistoric descriptions of Aztec society pertain to the imperial period after 1428 .

The analysis of these rapid and fundamental sociocultural changes requires fine-grained archaeological chronologies. The long established sequence of Early, Middle, and Late Postclassic periods (e.g., Sanders et al. 1979; see also Parsons et al. 1996) is simply not adequate to monitor such processes as rapid urbanization, imperial expansion, or economic transformation. In a general treat- ment of this theme, Smith (1992a) applied Fernand Braudel's (1980) concepts of temporal rhythms to the issue of chronological refinement. Sociocultural processes operate at a variety of temporal scales, and archaeologists should attempt to match the degree of resolution of their chronologies to the temporal scales of the processes they study. For example, broad patterns of environmental adaptation change slowly, and longer time periods may be adequate for their analysis. The 200 -year periods of the traditional chronology are appropriate for the issues of settlement patterns and adaptations addressed by Sanders et al. (1979). But now that attention has turned to more rapidly occurring processes such as imperial expansion or urbanization, archaeologists need finer chronologies (see Smith 1987: Smith and Doershuk 1991). The articles in this Special Section are responses to this need, and signal a new period of methodological and substantive advance in Aztec archaeology.

\section{BACKGROUND}

Yautepec was the capital city of a Postclassic polity located in the central part of the state of Morelos (see Figure 2 in Parsons et al. 1996). Several smaller city-states in the Yautepec Valley were subject to the ruler of Yautepec, and all of these polities were subject to the Triple Alliance through the Huaxtepec tributary province. Yautepec was first settled in the Early Postclassic period, and then expanded considerably in each of the Middle and Late Postclassic periods. It reached its maximum extent of approximately 210 ha by 1520 (Smith et al. 1994).

The ceramics described in this article are from residential excavations conducted in 1993 by Smith and Cynthia Heath-Smith (Smith 1994; Smith et al. 1996). These are the first excavations of houses from an Aztec urban center in central Mexico, and as such they provide a unique database for examining processes of change in a provincial area of the Aztec empire. The goals of the excavations were to recover data for the analysis of processes of urban- 
ization and imperial incorporation at the household level. Seven houses with associated middens were excavated, as well as a number of domestic middens without adjacent architecture. The middens contained particularly dense artifact deposits (most sherd densities are over 2,500 sherds per cubic meter) that are ideal for the kind of socioeconomic analyses that are needed to address household-level issues.

The goal of the chronological research described in this paper was to produce a finer sequence of phases in order to study changing social, economic, and cultural processes at Yautepec. To construct the Yautepec chronology, we used a set of ceramic variables to order groups of collections. First, we quantified ceramic types from excavated domestic middens and used descriptive statistics and previous research to identify ceramic variables that may be temporally sensitive. Next, we made a preliminary ordering of these variables using multidimensional scaling. This approach was not satisfactory, so we turned our attention to cluster analysis methods. Specifically, we used $k$-means cluster analysis to group collections of ceramics into sets or groups. The ordering of these groups was then established through known patterns of change in individual ceramic types. This produced a hypothetical solution that was tested by comparison with stratigraphic relationships among the groups and with radiocarbon dates. The success of these tests indicated that the groups were indeed arranged in a chronological order, and they could be considered ceramic phases. We then used calibrated radiocarbon dates to assign calendar dates to the phases.

Our new ceramic chronology for Yautepec includes four Postclassic phases and one Early Colonial phase (Figure 1). Ceramic markers of the Early Postclassic Epecapa phase are present in surface collections at Yautepec and other sites in the Yautepec Valley, but they were not recovered in excavations at Yautepec. The Epecapa phase and other periods prior to the Postclassic epoch will be

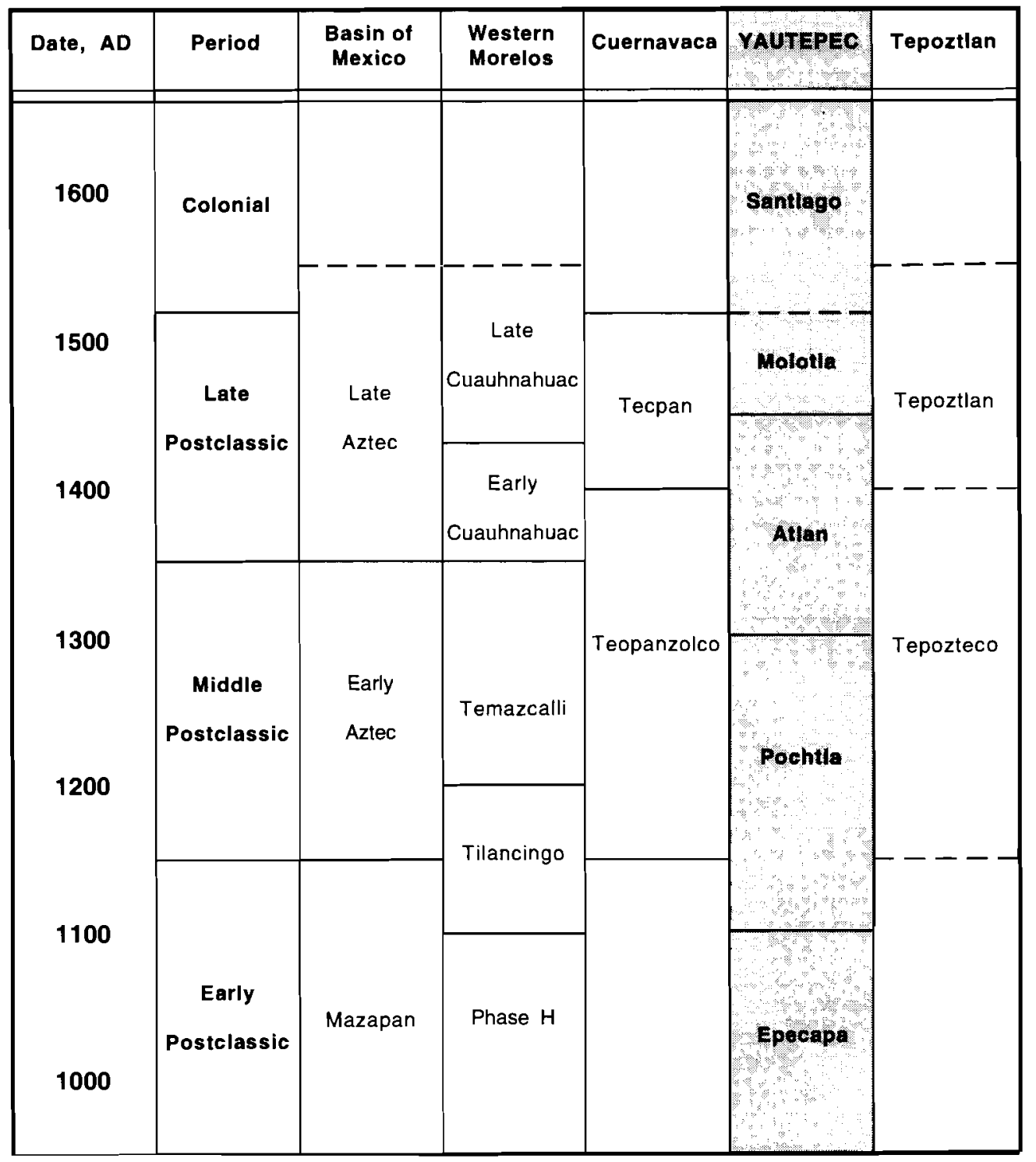

Figure l. The new Postclassic ceramic chronology for Yautepec compared with other central Mexican chronologies. Dashed lines indicate phase transitions with uncertain dates. 
described in later papers dealing with the regional survey (see Cascio and Hare 1996). The Middle and Late Postclassic periods are represented by three phases, which we call Pochtla, Atlan, and Molotla. The Pochtla phase covers the Middle Postclassic time period, while the Atlan and Molotla phases are subdivisions of the Late Postclassic period. The Early Colonial period is designated the Santiago phase. ${ }^{1}$

\section{APPROACHES TO ARCHAEOLOGICAL SERIATION}

George Cowgill defines seriation as "any technique for arranging a set of entities into a sequence such that, starting from any specific entity, the other entities most similar to it are closest to it in sequence" (Cowgill 1972:381). The object of seriation is to produce a sequence that models the passage of time. Quantitative seriation methods were pioneered in the 1950 s by Ford (1962) and Robinson (1951). The introduction of computers to archaeology in the 1960s led to an explosion of methodological studies exploring various seriation techniques (e.g., Cowgill 1972; Drennan 1976a; Dunnell 1970; Johnson 1972; LeBlanc 1975; Marquardt 1978). Productive empirical research lagged behind methodological advances, however, and archaeologists were slow to apply quantitative seriation methods to solve specific problems in archaeological chronology. There are still only a handful of published quantitative seriations from Mesoamerica (Curet et al. 1994; Drennan 1976a, 1976b; Smith and Doershuk 1991). The most common techniques employed in quantitative seriation studies are multidimensional scaling, cluster analysis using both hierarchical and $k$-means methods, factor analysis, and correspondence analysis (Duff 1996; Marquardt 1978). Our approach to seriation differs from that advocated by many of the methodological studies of the 1970s in our use of ceramic types instead of attributes, and in our use of clustering methods instead of multidimensional scaling.

\section{Attributes vs. Types}

As noted above, in our seriation of Postclassic contexts at Yautepec we chose to employ ceramic types rather than attributes. Many of the seriation studies of the 1970s argued that attributes are more sensitive to change than are types, and are thus superior for quantitative seriation (e.g., LeBlanc 1975; Marquardt 1978). Smith's initial seriation of ceramics at Xochicalco employed attributes to successfully refine the Postclassic chronology at that site into five phases (Smith 1983, 1987). That study involved the detailed study of fewer than 30 excavated ceramic lots. Later residential excavations at the nearby Postclassic sites of Cuexcomate and Capilco produced over 1,000 ceramic lots, most with several hundred sherds each. Because of the subtle nature of Postclassic ceramic change in western Morelos, only a small number of ceramic collections from these sites could be assigned initially to the new ceramic phases with confidence. In order to classify the remaining collections into phases, type frequencies were calculated and discriminantfunction analysis applied to the data. This operation was successful, resulting in the accurate chronological classification of most collections (Smith and Doershuk 1991).

The discriminant-function analysis at Cuexcomate and Capilco established that ceramic type frequencies could accurately moni-

'We took the phase names from ethnohistoric descriptions of Early Colonial barrios of Yautepec (Hinz et al. 1983; Martin 1985). tor chronological change in western Morelos. This was encouraging, as the sheer numbers of sherds excavated at these sites (nearly 500,000 in all) made attribute coding impractical for more than a relatively small sample of the total ceramics. Recently, Duff (1996) published the first explicit comparison of ceramic types and attributes as data for quantitative seriation. He was able to replicate LeBlanc's (1975) attribute-based seriation of deposits at the Pueblo de los Muertos site in New Mexico using only types. Duff points out a major advantage of using types over attributes-the seriation can employ a larger number of the sherds, often representing a larger number of provenience units. He concludes:

This presentation has demonstrated that it is possible to achieve accurate, fine-grained temporal seriation using type frequencies. ... Type-based analysis of large assemblages is more feasible than detailed attribute coding in most instances. In general, I suggest that it would be preferable to type all (or a substantial percentage) of the sherds in a large collection rather than record attributes on a much smaller subsample [Duff 1996:98, 99].

Based upon the success of ceramic types in monitoring Postclassic chronological change in western Morelos, we decided to use type frequencies rather than attributes for the Yautepec seriation. The large number of excavated ceramics at Yautepec (over one million sherds from five months of excavation) made attribute recording a daunting task. We plan to conduct attribute-based analyses of vessel function and other issues in the future, but at this stage of the analysis only type frequencies are available (and from only several hundred of the 1,500 ceramic lots). The success of our seriation provides additional support for Duff's (1996) findings on the usefulness of types for quantitative seriation.

\section{Continuous Change vs. Periodization}

Multidimensional scaling is probably the most common contemporary seriation method (see Kruskal and Wish [1978] on multidimensional scaling). The similarities among the units to be seriated are portrayed graphically, usually in a two-dimensional plot. When there is chronological structure in the data set, the passage of time follows either a linear axis or else a horseshoe-shaped curve. Successful multidimensional-scaling seriations from Mesoamerica are those of Curet et al. (1994), Drennan (1976a, 1976b), and Smith (1983, 1987; Smith and Doershuk 1991). The inferred time curve of a multidimensional-scaling seriation is compatible with the views of some archaeologists who have advocated the study of continuous change rather than the step-like patterns imposed by periodization (e.g., Plog 1974). Smith has argued against the notion of "continuous change" as follows:

The continuous-vs.-steps issue is a question of scale and meth-
ods. In order to make comparisons between different points in
time, periodization is required, because it is methodologically
not possible to study "continuous change." The methods do not
exist that can isolate and analyze instantaneous occurrences, and
even if this were possible, which of the nearly infinite instances
would we choose to analyze? The real issue is then the degree
of refinement of the chronology employed [Smith 1992a:27)].

A continuous seriation curve must be divided into periods or phases if we are to compare the results with other sites or areas. Chronological phases assume, for purposes of analysis, consistency within a group and across a period of time (Michels 1973:11). 
Our periodization of the Yautepec sequence does not derive from the adoption of a model of discrete stages or step-like cultural change. Rather it results from acknowledgment of the limited resolution of our methods and data. An additional reason for favoring a phase model over a continuous-change seriation model is that scaling techniques tend to be sensitive to sample size and the effects of nontemporal variation in the data. Dunnell long ago pointed out problems and errors that can occur in seriations when such nontemporal factors are not sufficiently controlled (Dunnell 1970: 313-315).

Although we initially experimented with multidimensional scaling of the Yautepec data (see below), we decided that cluster analysis was a more appropriate method given our goals of defining ceramic phases. The cluster-analysis approach to seriation differs from other seriation methods (such as Fordian seriation, multidimensional scaling, or factor analysis) by grouping or clustering individual collections rather than arranging them in a sequential order (see Aldenderfer and Blashfield [1984] on cluster analysis). Although some archaeologists object to the use of the term "seriation" to describe this approach (Robert Dunnell, personal communication 1996), we disagree for two reasons. First, the arrangement of the groups (if not the individual collections) into a chronological order fits most definitions of seriation in a narrow sense; one is simply seriating groups, not collections. Rouse (1967:164-165), for example, calls this procedure the seriation of components (see also Spaulding 1978:27). Second, the clusteranalysis approach is closely related to the traditional quantitative seriation of collections in its use of ceramic frequencies for the relative dating of archaeological deposits. It seems reasonable to broaden the definition of "seriation" to include clustering methods if only to provide a convenient way of talking about quantitative, artifact-based, relative-dating methods in general (see Duff [1996] or Spaulding [1978] for examples of this usage). There are too few applications of these methods, and one goal of this paper is to demonstrate the value of statistical techniques for the construction of archaeological chronologies. Many of these techniques can be applied relatively easily using widely available commercial software, such as SYSTAT (Wilkinson 1990) or SPSS (Norusis 1992a, 1992b). The techniques used in this project, including data processing and both tabular and graphical output, are all available in these general-purpose statistical packages.

\section{PREPARATION FOR THE CERAMIC SERIATION}

\section{Deposits and Ceramics}

The primary data used in this analysis consist of counts of ceramic types from 276 excavated contexts at Yautepec. The 1993 excavations resulted in the definition of 1,465 spatially distinct contexts, most of which are excavated levels. One-third to one-half of these contexts are from midden deposits (as identified through a combination of subjective field judgments, spatial associations with structures, and measures of artifact quantity and diversity). We used only midden contexts in the initial seriation ordering. There are several reasons for this, including the abundance of artifacts and diversity of types in middens (which yield large samples to work with) and the elimination of variation due to formation processes (Schiffer 1987). For the discriminant-function phasing stage, we included ceramic collections from a wider variety of context types. The majority of the 1.2 million excavated sherds still remain to be classified. The 276 collections used here were selected for classification in order to provide a good sample for the seriation; they cover all time periods and all excavations, and the best stratigraphic deposits are well represented.

The ceramics have been classified into types that combine attributes of vessel form and surface finish. The Yautepec ceramic classification is based upon the system first defined by Smith in western Morelos (Smith 1983, 1987, 1992b), and which he is continuing to refine. There are six form classes: bowls, jars, basins, comales, other vessels, and miscellaneous artifacts. Types are divisions of these classes. For the first four classes, types are defined on the basis of surface finish. The widest variation is within the bowls class, for which there are over 30 types based on painted decoration. For the final two form classes, types are defined by combinations of vessel form and surface finish.

Smith established the initial typology for Yautepec in 1992 and 1993, and since then new categories for Postclassic and Colonial ceramics have been added by both authors. There are more than 100 ceramic types for the Postclassic and Early Colonial periods discussed in this paper. More-refined ceramic analyses will be used to address other research questions. For example, minimum number of vessel estimates will be used for domestic ceramic comparisons, attribute associations will be used for more detailed characterizations of ceramic variability, and attributes and subtypes of key types are being defined for studies of ceramic production and distribution.

\section{Selection of Variables}

Out of the more than 100 types in the ceramic typology, we selected 14 types for use in the seriation on the basis of both external and internal criteria. Externally, we tried to include types that had been identified as chronologically sensitive in the Basin of Mexico (Hodge and Minc 1990; Minc 1994; Parsons 1966; Sanders et al. 1979) or elsewhere in Morelos (Norr 1987; Smith 1983; Smith and Doershuk 1991). Internally, we focused on decorated types because their high stylistic component (relative to plainwares) makes them good candidates for chronological markers (Rowe 1959; Sackett 1977). We examined descriptive statistics for most types and eliminated very rare categories as unreliable for quantitative analysis. Unfortunately many chronologically sensitive types, particularly imported decorated wares, are quite rare and could not be used in this seriation. We are currently exploring methods to use these types as a supplement to the quantitative seriation.

In a few cases we combined rare types in order to boost the frequency of the resulting variable. For example, imported Aztec III Black-on-orange vessels from the Basin of Mexico are included in the classification under three types: bowls, spinning bowls, and molcajetes; these are combined into a single variable for the seriation. In other cases, lumping may mask the chronological sensitivity of individual types. For example, we combined Aztec I Black-on-orange with Aztec II Black-on-orange, as both are recognized Middle Postclassic types, although new evidence suggests that their temporal distributions in the Basin of Mexico may not be identical (see Parsons et al. 1996). The following ceramic lypes are used in the seriation: Teopanzolco polychromes, Tepozteco Bichrome, black-on-white jars, Guinda, C Polychromes, B-7 Polychrome. Aztec III Black-on-orange, Aztec I/II Black-onorange, Tlahuica Polychrome jars, Xochimilco Polychrome, saht madors (frying-pan incense burners), copas, scored incensarios, and glazed earthenware. These variables are discussed below. 


\section{CERAMIC SERIATION}

In order to simplify the analysis and reduce variability resulting from small samples and mixed or eroded ceramics, the initial seriation was limited to ceramic collections from well-defined midden contexts with more than 200 total sherds (the mean number of sherds per collection is 1,671, and the standard deviation is 1,252 ; the minimum collection size is 252 , and the maximum is 5,139 ). This resulted in a manageable set of 47 ceramic collections. Type frequencies in these collections were expressed as percentages of total sherds. We standardized the variables using $\mathrm{Z}$-scores to ensure that each ceramic type contributed equally to the analysis.

We initially experimented with multidimensional scaling to produce a chronological ordering of the ceramic collections. We tried various combinations of variables, and eliminated divergent collections that were outliers in initial runs. The resulting twodimensional-scaling solutions took the form of temporal curves, putting many of the stratigraphically related collections in correct order. Although these results were successful in producing a temporal ordering, it was not clear how to divide the sequence into phases. Also, we had doubts about the ability of a continuous seriation curve to accurately and precisely monitor small increments of temporal change (see earlier discussion). For these reasons, we turned to $k$-means cluster analysis as a more appropriate approach for allocating collections to chronologically significant groups or phases.

\section{Cluster Analysis and Periodization}

For the identification of groups of cases that could be interpreted as chronological phases, we employed $k$-means cluster analysis. Cluster analysis uses the same data as multidimensional scaling but groups cases into homogenous clusters rather than forming a comprehensive scaling. Compared with multidimensional scaling, cluster analysis reduces the subjectivity in the determination of boundaries between chronological phases. $K$-means cluster analysis uses an iterative procedure for calculating group centers and assigning cases to those groups. This procedure differs from the more widely used hierarchical clustering techniques in that the user determines the number of clusters a priori, and there is no hierarchical relationship among the clusters that are defined. These features make $k$-means cluster analysis more appropriate than hierarchical cluster analysis for the kind of problem-oriented seriation we are doing.

For the cluster analysis we used the variables listed above (Table 1) but left out glazed earthenware. Similarity between each pair of ceramic collections was measured with Euclidean distance. We produced various cluster solutions using different combinations of variables, but the majority of cases consistently maintained their group membership, and a few cases shifted between clusters. When the number of clusters was increased, the amount of shifting between clusters increased. As the number of clusters increased, groups of one or two cases were pulled out as clusters and the variability within clusters increased in relation to distances between clusters. The greatest stability resulted from solutions of two clusters. We used a two-cluster solution to separate out Middle and Late Postclassic cases. Then two-cluster solutions were applied to each of the resulting clusters. For the Late Postclassic, the subdivision was effective (as determined by stratigraphy and patterns of ceramic change), whereas the two clusters of Middle Postclassic cases did not appear to have chronological significance. We therefore chose to maintain three groups, one for the Middle Postclassic and two for the Late Postclassic period.

The three groups can be interpreted as chronological phases based on the predicted temporally sensitive variables associated with each group and the stratigraphic relations among excavation

Table I. Frequencies of Ceramic Variables by Phase

\begin{tabular}{|c|c|c|c|c|c|c|c|c|c|c|}
\hline \multirow[b]{2}{*}{ Variable } & \multicolumn{2}{|c|}{ Pochtla } & \multicolumn{2}{|c|}{ Atlan } & \multicolumn{2}{|c|}{ Molotla } & \multicolumn{2}{|c|}{ Santiago } & \multicolumn{2}{|c|}{ Total } \\
\hline & Mean $(\%)$ & S.D. & Mean $(\%)$ & S.D. & Mean $(\%)$ & S.D. & Mean $(\%)$ & S.D. & Mean $(\%)$ & S.D. \\
\hline Teopanzolco polychromes & .64 & $(.34)$ & .34 & (.19) & .13 & $(.12)$ & .04 & $(.06)$ & .33 & $(.29)$ \\
\hline Tepozteco Bichrome & .23 & $(.19)$ & .02 & $(.05)$ & .03 & $(.06)$ & .02 & (.03) & .07 & $(.13)$ \\
\hline Black-on-white jars & .54 & $(.69)$ & .10 & $(.21)$ & .04 & $(.07)$ & - & - & .18 & $(.41)$ \\
\hline Guinda & 3.69 & $(1.42)$ & 2.04 & (1.03) & 1.59 & $(.72)$ & 1.04 & $(.21)$ & 2.26 & $(1.33)$ \\
\hline C Polychrome & .45 & $(.44)$ & 1.18 & $(.69)$ & .90 & $(.74)$ & .38 & $(.10)$ & .87 & $(.70)$ \\
\hline B-7 Polychrome & .14 & $(.18)$ & .77 & (.69) & 1.49 & $(1.20)$ & .27 & $(.25)$ & .83 & $(.96)$ \\
\hline Aztec III Black-on-orange & .08 & $(.15)$ & .23 & $(.15)$ & .45 & $(.27)$ & .64 & $(.35)$ & .28 & $(.25)$ \\
\hline Aztec I and II Black-on-orange & .09 & $(.15)$ & .02 & $(.04)$ & .03 & $(.11)$ & - & - & .04 & $(.10)$ \\
\hline Tlahuica Polychrome jars & .55 & $(.21)$ & .10 & $(.09)$ & .08 & (.11) & .04 & $(.06)$ & .20 & $(.24)$ \\
\hline Xochimilco Polychrome & .04 & $(.06)$ & .19 & $(.23)$ & .15 & (.19) & - & - & .13 & $(.19)$ \\
\hline Sahumadors & .31 & $(.20)$ & .53 & $(.25)$ & .31 & $(.28)$ & .32 & $(.24)$ & .39 & $(.27)$ \\
\hline Copas & .03 & $(.06)$ & .15 & $(.17)$ & .12 & $(.16)$ & - & - & .10 & (.15) \\
\hline Scored incensarios & .19 & (.08) & .12 & $(.09)$ & .03 & (.05) & .02 & $(.03)$ & .10 & $(.10)$ \\
\hline Glazed earthenwares & - & - & - & - & - & - & 1.22 & $(.46)$ & .05 & $(.25)$ \\
\hline Total sherds & 1,120 & 515 & 1,682 & $\mathrm{I}, 185$ & 2,186 & 1,579 & 1,065 & 1,060 & 1,671 & 1,252 \\
\hline Number of collections & 12 & & 19 & & 16 & & 2 & & 49 & \\
\hline
\end{tabular}

Note: These frequencies pertain to the 47 collections used in the initial cluster analyses, plus the two Santiago-phase collections. Please see Note 5 regarding the usefulness of these data for socioeconomic interpretations. 


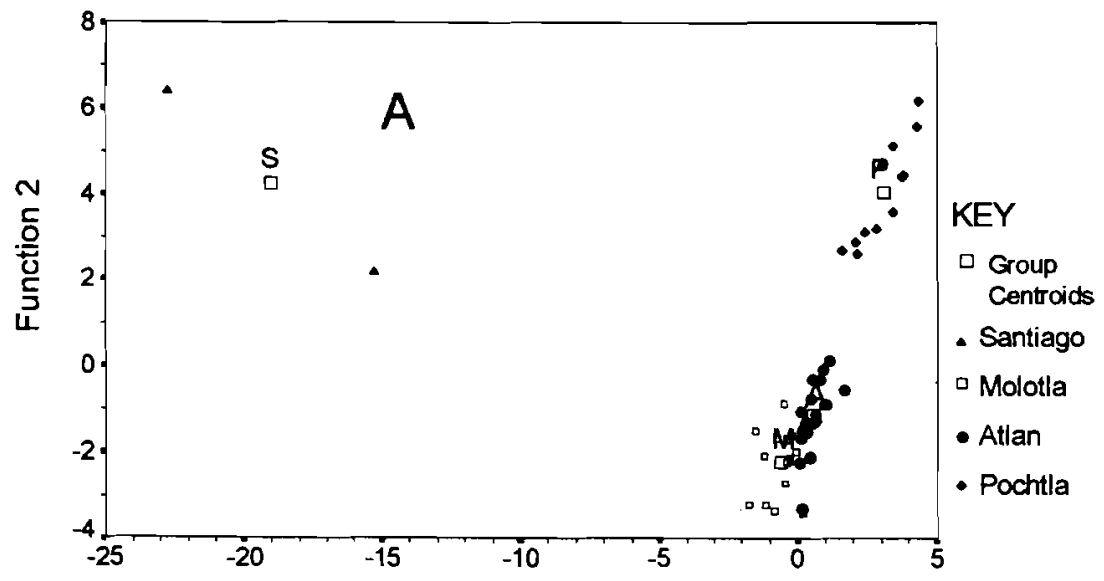

Function 1

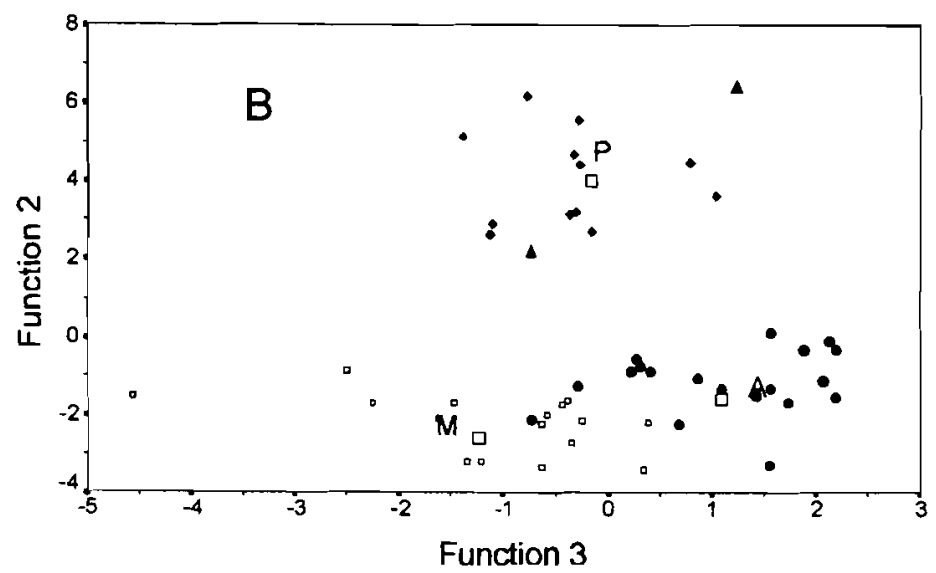

Figure 2. Plots of the discriminant functions. Function 1 distinguishes the Santiago phase [Early Colonial] from the Postclassic phases, Function 2 distinguishes the Middle Postclassic Pochtla phase from the Late Postclassic phases, and Function 3 distinguishes the two Late Postclassic phases, Atlan and Molotla. units (see below). The three phases cover the Middle and Late Postclassic periods. The Colonial-period ceramic collections were classified by the cluster analysis to the Molotla phase in the threegroup model. We later separated out the Colonial collections as a separate phase in the disciminant function stage. ${ }^{2}$

\section{Discriminant-Function Phasing}

We turned to discriminant-function analysis to classify the $229 \mathrm{ce}-$ ramic collections that were not used in the $k$-means cluster analysis (see Tatsuoka [1970] on discriminant-function analysis). The cases used in the cluster analysis were included in the discriminantfunction definition stage as members of the three identified groups or phases. Discriminant-function analysis constructs linear functions of the variables that serve to distinguish or discriminate between the groups. The same set of variables was employed in both the discriminant functions and $k$-means cluster analyses, without

${ }^{2}$ We then tried four-cluster solutions using glazed earthenware as a variable. This category overwhelmed the other ceramic variables in the identification of the Colonial phase. A number of Postclassic collections with a single sherd of glazed earthenware (from mixing) were incorrectly classified into the Colonial group. Because of this distortion, we omitted glazed earthenware at this stage of the analysis and pursued three-cluster solutions. the glazed-earthenware category at first. The functions produced using the previously grouped cases are then used to classify the ungrouped cases into the three phases. All discriminant runs, using various combinations of variables, resulted in over $90 \%$ accuracy in the classification of the previously grouped cases; this is a high degree of accuracy for discriminant-functional classification procedures.

For the next stage we defined a fourth group for the Colonial period using two ceramic collections from Early Colonial middens. These two cases are from a dense, unmixed midden deposit dated to the Early Colonial period on the basis of glazed-earthenware ceramics, bovid bones, and other markers of Colonial-period occupation. The discriminant-function analysis was conducted again using four groups and included the additional variable of glazed earthenware. Again the success of the discriminant classification of grouped cases was over $90 \%$.

The results of the discriminant-function analysis are plotted in Figure 2. Three functions were produced (the number of functions is always one less than the total number of groups in the analysis). Function 1, the most powerful function, separates the Santiago phase from the three Postclassic phases. Function 2 separates the Middle Postclassic Pochtla phase from the two Late Postclassic phases. Function 3, the least powerful, distinguishes the Atlan and Molotla phases of the Late Postclassic period. The relative ordering of the functions replicates our subjective judg- 
ments on the distinctiveness of the four ceramic complexes. The Santiago phase is the easiest to recognize from the glazed earthenwares and other distinctive (but rare) types and attributes. It is also relatively easy to distinguish Middle and Late Postclassic ceramics (Function 2), except with very small collections. The separation of the Atlan and Molotla phases was first established by the seriation, and this is the most subtle distinction among phases in the sequence. Preliminary inspection of ceramics and stratigraphy had suggested the presence of two Late Postclassic phases (based partially upon Smith and Doershuk's [1991] earlier chronological research in western Morelos and Cuernavaca and Smith's continuing research), but we could not identify these before the cluster analyses described here.

\section{STRATIGRAPHIC PATTERNS}

Our fundamental criterion for assessing the success of the ceramic seriation was stratigraphy. This was done by hand as follows. We first prepared schematic drawings of all of the excavated contexts that show natural strata, excavated levels, and architectural remains (where present). Output from the discriminant-function phasing included a list of all collections and their assigned ceramic group or phase. These assignments were marked on the drawings. The resulting phasings were then evaluated visually. In most cases, the seriated order of the ceramic collections matched the stratigraphic order of their deposits.

Table 2 summarizes the stratigraphic "success" of the chronological classification of excavation units. "Correct" relationships describe cases where the stratigraphic order of two deposits is correctly predicted by their seriated collections. "Incorrect" relationships of two types are included: inversion (where the relative ceramic ordering differs from the stratigraphy), and mismatching (when two collections from the same physical stratum are seriated to different phases). We were conservative in judging stratigraphic success. Each deposit is counted only once, even when it is represented by more than one seriated collection. For example,

Table 2. Stratigraphic Relationships of Seriated Deposits

\begin{tabular}{|c|c|c|c|}
\hline \multirow[b]{2}{*}{ Unit } & \multirow[b]{2}{*}{ Correct } & \multicolumn{2}{|c|}{ Incorrect } \\
\hline & & Fill & Other \\
\hline 501 & 15 & 2 & 2 \\
\hline 502 & 3 & 2 & - \\
\hline 503 & 10 & - & - \\
\hline 504 & 1 & - & 1 \\
\hline 505 & 9 & 1 & - \\
\hline 506 & 5 & 3 & 4 \\
\hline 508 & 3 & - & 2 \\
\hline 509 & 8 & 2 & 4 \\
\hline 510 & 1 & - & - \\
\hline 512 & 13 & 6 & 3 \\
\hline 515 & 2 & - & - \\
\hline 517 & 1 & - & 2 \\
\hline Total & 71 & 12 & 18 \\
\hline
\end{tabular}

Note: See text for discussion of the meaning of "correct" and "incorrect" stratigraphic relationships. if each of two superpositioned strata had four seriated collections, all in correct order, these eight collections are counted as a single case in Table 2. If several collections from a stratum agreed on its phasing but one differed, the case is counted as an incorrect stratigraphic relationship in the table.

Overall we feel that the seriation has strong stratigraphic support. Nearly half of the "errors" were in architectural fill contexts, where deposits of mixed phases are expected. Many of the other errors are aberrant ceramic collections in which various nonchronological factors (such as small collection sizes and various cultural and noncultural formation processes) cause the type frequencies to depart from the means for their phase. Beyond the stratigraphic evidence supporting the seriation is the independent evidence of radiocarbon dates.

\section{DATING THE PHASES}

We have assigned provisional calendrical dates to the ceramic phases on the basis of radiocarbon dates. Most of the 17 carbon samples were selected for dating in order to assign dates to wellphased midden contexts; several were selected to date specific features. All samples were carbonized wood, and the radiocarbon ages reported here have been corrected for isotope fractionation through measurement of the ${ }^{13} \mathrm{C} /{ }^{12} \mathrm{C}$ ratio (expressed as $\delta^{13} \mathrm{C} \%$ ). The samples were processed by Herbert Haas of the Desert Research Institute. Most were run using high-precision conventional radiocarbon processing techniques; five of the smallest samples were run using the accelerator technique in Zurich, Switzerland. All dates were calibrated using the OxCal software, version 2.18 (Ramsey 1995), which employs the high-precision 10-year determination scale (Stuiver and Becker 1986; see also Stuiver and Kra 1986; Stuiver et al. 1993).

Table 3 lists the carbon samples with information on their provenience and the ceramic phase associations of the proveniences. Table 4 lists the calibrated dates with one-sigma and two-sigma ranges; the dates are arranged in chronological order within ceramic phases. We provide two methods of graphical presentation of the calibrated dates. Figure 3, produced by the OxCal 2.18 software, presents 14 of the 17 dates. ${ }^{3}$

The probability distribution for each date is shown, along with the one-sigma and two-sigma ranges presented as horizontal brackets below the probability curve. At the left is the uncalibrated radiocarbon age (and sigma) of each sample. A number of the dates have multimodal distributions (and multiple date ranges at one sigma, two sigma, or both), resulting from fluctuations of the calibration curve during Postclassic times (Stuiver and Kra 1986; Stuiver et al. 1993). Date G (Figure 4) illustrates such a bimodal probability distribution as calculated by the OxCal software. Figure 5 depicts the one-sigma ranges for the entire set of 17 calibrated dates (although the ranges of two dates, $\mathrm{C}$ and $\mathrm{Q}$, extend beyond the limits of this graphic). Because of the nature of the probability distributions of calibrated dates, interpretations should be based upon ranges and modes, not calibration-curve intercepts.

\footnotetext{
${ }^{3}$ Three dates whose two-sigma distributions extend beyond the limits of Figure 3 are not included (Dates E, C, and Q). When these dates are plotted with the others, the $\mathrm{x}$-axis scale is compressed, making it difficult to examine the total group of dates. The three dates are included in Figure 5, although the one-sigma ranges of Dates $\mathrm{C}$ and $\mathrm{Q}$ extend beyond the limits of that figure.
} 
Table 3. Radiocarbon Dates from Yautepec

\begin{tabular}{|c|c|c|c|c|c|c|}
\hline \multirow[b]{2}{*}{ Sample } & \multirow{2}{*}{$\begin{array}{c}\text { Field } \\
\text { Number }\end{array}$} & \multirow{2}{*}{$\begin{array}{l}\text { Laboratory } \\
\text { Number }\end{array}$} & \multirow{2}{*}{$\begin{array}{l}\text { Provenience } \\
\text { Code }\end{array}$} & \multicolumn{2}{|c|}{ Ceramic Depth } & \multirow[b]{2}{*}{ Context } \\
\hline & & & & Phase & B.S. & \\
\hline A & $501-4$ & DRI-2943 & $501-047-02$ & $\mathrm{M}$ & 22 & hearth \\
\hline B & $501-6$ & DRI-2945 & $501-087-01$ & $\mathrm{M}$ & 19 & hearth \\
\hline C & $501-8$ & ETH-14811 & $501-115-01$ & $\mathbf{M}$ & 17 & Burial 2 \\
\hline $\mathrm{D}$ & $501-29$ & DRI-3026 & $501-212-07$ & $\mathrm{P}$ & 65 & midden, Capa 7 \\
\hline E & $501-41$ & DRI-3027 & $501-362-03$ & A & 40 & midden, Capa 9 \\
\hline $\mathrm{F}$ & $501-46$ & DRI-2944 & $501-382-05$ & $\mathrm{P}$ & 42 & midden, Capa 7 \\
\hline G & $503-6$ & DRI-2942 & 503-034-10 & A & 78 & midden, Capa 4 \\
\hline $\mathrm{H}$ & $503-10$ & ETH- 14812 & $503-034-19$ & $P$ & 134 & midden. Capa 4 \\
\hline I & $503-28$ & DRI-2946 & $503-094-03$ & A & 27 & midden, Capa 2 \\
\hline $\mathrm{J}$ & $505-4$ & DRI-3021 & $505-024-07$ & $\mathrm{P}$ & 74 & midden, Capa 9 \\
\hline K & $505-7$ & DRI-3022 & $505-224-03$ & $\mathrm{P}$ & 50 & midden, Capa 9/10 \\
\hline $\mathrm{L}$ & $506-1$ & DRI-3023 & $506-604-08$ & M & 53 & midden, Capa 10 \\
\hline $\mathbf{M}$ & $509-30$ & ETH-14813 & $509-702-03$ & $S$ & 36 & midden, Capa 12 \\
\hline $\mathrm{O}$ & $512-14$ & ETH-14814 & $512-084-0$ & A & 85 & construction collapse, Capa 6 \\
\hline$P$ & $512-16$ & ETH-14815 & $512-114-07$ & A & 95 & between midden (Capa 8) and Capa 6 \\
\hline Q & 512.27 & DRI-3024 & $512-181-18$ & $\mathrm{P}$ & 120 & midden, Capa 39, under structure \\
\hline $\mathbf{R}$ & $512-29$ & DRI-3025 & $512-064-10$ & A & 100 & midden, Capa 26, early structure \\
\hline
\end{tabular}

"Phases are represented by $\mathrm{P}=$ Pochtla, $\mathrm{A}=$ Atlan, $\mathrm{M}=$ Molotla, $\mathrm{S}=$ Santiago.

In line with this approach, the OxCal software does not supply intercept data.

Our provisional calendar dates for the four ceramic phases are: Pochtla-A.D. 1100-1300; Atlan-A.D. 1300-1440; MolotlaA.D. 1440-1540; Santiago-A.D. 1540-?. These are based on subjective evaluations of the ranges and probability distributions of the 17 radiocarbon dates. We hope to improve upon these results by running additional dates in the future and by applying quantitative procedures to the problem of dating phase boundaries. ${ }^{4}$ The following discussion provides our justification for the phase dates listed above.

The Pochtla phase marks the start of the Middle Postclassic period at Yautepec. As in the Basin of Mexico, the Middle and Late Postclassic periods in Morelos witnessed a single evolving cultural tradition whose ceramics and other material traits were quite distinct from those of the Early Postclassic period. The lack of chronometric dates from Epecapa contexts makes it difficult to establish the timing of the Epecapa/Pochtla transition with confidence. There are no excavated deposits from the Epecapa phase, and the Epecapa ceramic complex was defined from surface collections.

Five of the six Pochtla-phase samples have one-sigma ranges largely or entirely within the time span of A.D. 1100-1280. For a variety of reasons it is always easier to determine the end date of a phase more reliably than the beginning date (Waterbolk 1983:63), and thus we regard 1100 as a highly provisional date for the start of the Pochtla phase. Date Q, from a Pochtla-phase deposit, has the largest error factor of any date, and we do not believe that its date range (A.D. 820-1160, one-sigma) is a reliable indicator of

${ }^{4}$ The irregular probability distributions of calibrated dates makes it difficult to use standard statistical techniques for their analysis. The $\mathrm{OxCal}$ software contains mathematical procedures for estimating phase boundaries from calibrated dates, but we have been unable to get these procedures to work correctly. the age of the Pochtla phase. Pochtla-phase ceramics share many types and attributes with Middle Postclassic ceramics from western Morelos and the Basin of Mexico (many of these traits were too rare to include in the seriation), and Smith (1996) has suggested that the Middle Postclassic ceramic complexes of central Mexico mark the beginning of Aztec culture.

The availability of chronometric dates from the Basin of Mexico is similar to Morelos: the Middle Postclassic period has some radiocarbon dates, stratigraphy, and well-described ceramics, whereas the Early Postclassic period lacks these features (see Parsons et al. 1996; Nichols and Charlton 1996). Based upon similarities in ceramics and other material culture, we think it is reasonable to hypothesize that the transition from Early Postclassic to Middle Postclassic assemblages in Morelos and the Basin of Mexico occurred at roughly the same time. For these reasons we are skeptical about Parsons et al.'s (1996) proposed extension of the Early Aztec (Middle Postclassic) ceramic phase back in time in the absence of stronger empirical support.

The transition between the Pochtla and Atlan phases marks the Middle to Late Postclassic change in central Mexico. The date of A.D. 1280 nicely divides the ranges of the relevant dates (see Figures 3 and 5). Date P, from an Atlan-phase midden in Unit 512, falls completely within the Pochtla-phase time range. There is a Pochtla occupation at the base of this deposit and the sample was probably from Pochtla-phase wood, perhaps a construction beam that was reused and then discarded during Atlan times. We have rounded the date for the start of the Atlan phase to A.D. 1300, which is a half-century earlier than the traditional starting date of other Late Postclassic phases in Morelos and the Basin of Mexico, A.D. 1350 (Sanders et al. 1979; Smith 1987; Smith and Doershuk 1991).

A number of well-established Late Postclassic ceramic markers appear for the first time in the Atlan phase, most notably Aztec III Black-on-orange (see below). There does not appear to be enough 
Table 4. Radiocarbon Ages and Calibrated Date Ranges

\begin{tabular}{|c|c|c|c|c|c|c|c|}
\hline \multirow[b]{2}{*}{ Sample } & \multirow{2}{*}{$\begin{array}{l}\text { Laboratory } \\
\text { Number }\end{array}$} & \multirow{2}{*}{$\begin{array}{c}\text { Radiocarbon } \\
\text { Age (B.P.) }\end{array}$} & \multirow[b]{2}{*}{$\delta^{13} \mathrm{C} \%$} & \multicolumn{2}{|l|}{ One Sigma } & \multicolumn{2}{|l|}{ Two Sigma } \\
\hline & & & & Cal A.D. Date Range & $P$ & Cal A.D. Date Range & $P$ \\
\hline \multicolumn{8}{|c|}{ Pochtla-phase samples } \\
\hline Q & DRI-3024 & $1048 \pm 150$ & $-24.9 \% c$ & $820-1160$ & 1.00 & $650-1250$ & 1.00 \\
\hline K & DRI-3022 & $892 \pm 84$ & $-25.1 \%$ & $1040-1210$ & 1.00 & $1000-1270$ & 1.00 \\
\hline \multirow[t]{3}{*}{$\mathrm{H}$} & ETH-14812 & $845 \pm 50$ & $-25.5 \%$ & $1060-1070$ & .03 & $1040-1270$ & 1.00 \\
\hline & & & & $1120-1140$ & .04 & & \\
\hline & & & & $1160-1260$ & .93 & & \\
\hline \multirow[t]{2}{*}{$\mathrm{J}$} & JDRI-302I & $827 \pm 97$ & $-25.8 \%$ & $1040-1090$ & .18 & $1010-1300$ & .99 \\
\hline & & & & $1120-1270$ & .82 & $1360-1380$ & .01 \\
\hline $\mathbf{F}$ & DRI-2944 & $785 \pm 48$ & $-25.3 \%$ & $1210-1275$ & 1.00 & $1120-1290$ & 1.00 \\
\hline \multirow[t]{3}{*}{ D } & DRI-3026 & $750 \pm 143$ & $-26.1 \%$ & $1050-1080$ & .07 & $1000-1440$ & 1.00 \\
\hline & & & & $1120-1320$ & .75 & & \\
\hline & & & & $1340-1400$ & .18 & & \\
\hline \multicolumn{8}{|c|}{ Atlan-phase samples } \\
\hline \multirow[t]{2}{*}{$\mathrm{P}$} & ETH- $\mid 4815$ & $760 \pm 55$ & $-19.4 \%$ & $1215-1285$ & 1.00 & $1160-1310$ & .97 \\
\hline & & & & & & $1350-1390$ & .03 \\
\hline $\mathbf{R}$ & DRI-3025 & $650 \pm 83$ & $-24.7 \%$ & $1270-1400$ & 1.00 & $1220-1430$ & 1.00 \\
\hline \multirow[t]{2}{*}{ G } & DR1-2942 & $634 \pm 47$ & $-24.3 \%$ & $1280-1320$ & .42 & $1270-1400$ & 1.00 \\
\hline & & & & $1340-1390$ & .58 & & \\
\hline \multirow[t]{2}{*}{ I } & DRI-2946 & $576 \pm 116$ & $-25.1 \%$ & $1280-1430$ & 1.00 & $1210-1530$ & .96 \\
\hline & & & & & & $1560-1640$ & .04 \\
\hline \multirow[t]{2}{*}{ O } & ETH-14814 & $520 \pm 55$ & $-22.5 \%$ & $1320-1350$ & .24 & $1290-1460$ & 1.00 \\
\hline & & & & $1390-1440$ & .76 & & \\
\hline $\mathrm{E}$ & DRI-3027 & $404 \pm 139$ & $-24.9 \%$ & $1400-1650$ & 1.00 & $1250-\ldots$ & 1.00 \\
\hline \multicolumn{8}{|c|}{ Molotla-phase samples } \\
\hline \multirow[t]{2}{*}{$\mathrm{L}$} & DRI- 3023 & $431 \pm 92$ & $-26.0 \%$ & $1400-1520$ & .74 & $1300-1360$ & .06 \\
\hline & & & & $1570-1630$ & .26 & $1380-1660$ & .94 \\
\hline \multirow[t]{2}{*}{ A } & DRI-2943 & $416 \pm 45$ & $-25.2 \%$ & $1430-1510$ & 1.00 & $1410-1530$ & .81 \\
\hline & & & & & & $1560-1630$ & .19 \\
\hline B & DRI-2945 & $388 \pm 117$ & $-25.9 \%$ & $1430-1640$ & 1.00 & $1250-\ldots$ & 1.00 \\
\hline \multirow[t]{4}{*}{ C } & ETH-14811 & $230 \pm 60$ & $-18.2 \%$ & $1520-1570$ & .15 & $1490-1700$ & .52 \\
\hline & & & & $1630-1690$ & .35 & $1720-1880$ & .42 \\
\hline & & & & $1730-1810$ & .45 & $1910-\ldots$ & .06 \\
\hline & & & & $1930-\ldots$ & .05 & & \\
\hline \multicolumn{8}{|c|}{ Santiago-phase samples } \\
\hline \multirow[t]{3}{*}{$\mathrm{M}$} & ETH- 14813 & $450 \pm 55$ & $-25.8 \% c$ & $1405-1485$ & 1.00 & $1320-1340$ & .02 \\
\hline & & & & & & $1390-1530$ & .87 \\
\hline & & & & & & $1560-1630$ & .11 \\
\hline
\end{tabular}

Note: The date ranges and probabilities were calculated by the OxCal 2.18 calibration software (Ramsey 1995). For each sample, the calibrated date range with the highest probability is indicated in boldface type.

information available yet to reconcile the differences between the traditional date (1350) and our proposed date (1300) for the start of the Late Postclassic period at Yautepec. Among the possibilities are: (1) the Late Aztec phase in the Basin of Mexico starts closer to 1300 than 1350 (this is not inconsistent with the Otumba dates; see Nichols and Charlton 1996); (2) the Atlan phase starts earlier than Late Aztec, and imports such as Aztec III Black-onorange do not appear at Yautepec until some time after the start of Atlan; or, perhaps some combination of these or other models is needed. Only additional chronological research will settle this question.

Of the six carbon dates from Atlan-phase deposits, one, Date P. pertains to a Pochtla time span, and one, Date E, has a very large error factor (the two-sigma range extends up to the present). The one-sigma ranges of the remaining four dates ( $R, G, I$, and $O$ ) fall between A.D. 1270 and 1440. Of the four dates from Molotlaphase contexts, one, Date $C$, is significantly younger than the others (see Table 4). This sample is from the vicinity of Burial 2 at Unit 501, which is clearly a pre-Hispanic interment. A Molotlaphase hearth, dated by Sample B, overlies part of the burial. The burial and hearth are at the base of the plow zone, and the sample from the burial was from the uppermost part, away from the hearth and only $17 \mathrm{~cm}$ below ground surface. The area around Unit 501 was farmed in the Colonial and modern periods, and we suggest that Sample C derives from the seventeenth- or eighteenth-century use of this area. The one sample from a Santiago-phase context, 


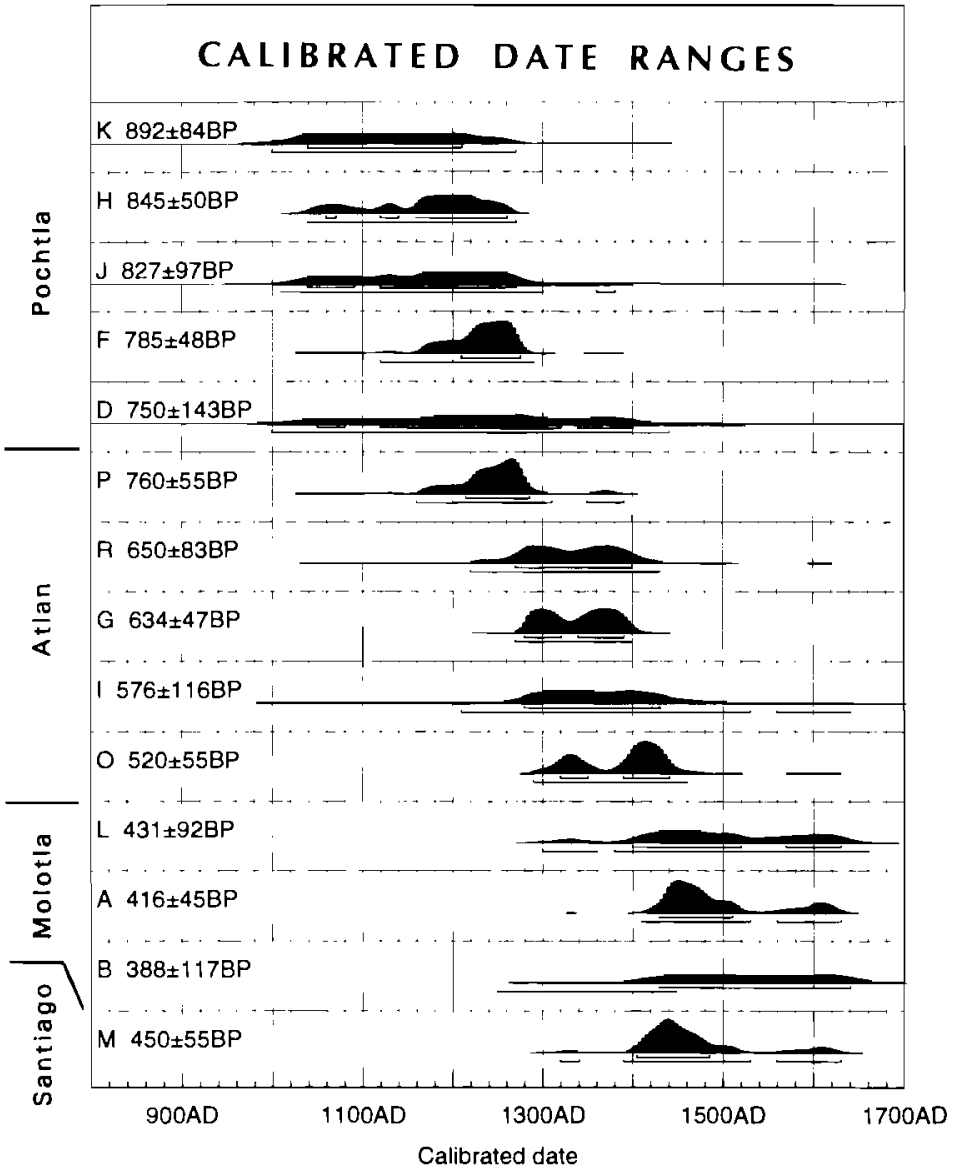

Figure 3. Calibrated radiocarbon dates from Yautepec. The dates are arranged by ceramic phase, with the uncalibrated radiocarbon ages and error factors provided on the left side. The horizontal brackets under each probability curve denote the onesigma (upper brackets, $67 \%$ probability) and two-sigma (lower brackets, $95 \%$ probability) ranges of the date. Three of the dates are not shown; these have two-sigma ranges that extend considerably earlier (Date Q) or later (Dates $C$ and $E$ ) than the other dates. The data are presented in Table 4. This graph was modified from the output of the OxCal 2.18 software (Ramsey 1995).
Date $\mathrm{M}$, most likely has a pre-Hispanic age (see Table 4 and Figure 3 ). The Santiago midden yielding this sample was associated with a house built initially in Molotla times and used into the Colonial period. The sample is probably from old wood, perhaps signaling the initial, Molotla-phase, construction of this house.
Date $\mathrm{M}$ and the remaining three Molotla-phase dates ( $\mathrm{L}, \mathrm{A}$, and B) have bimodal probability distributions (see Figure 3). For each date, the earlier mode has the highest probability, and these modes all fall between A.D. 1400 and 1540 (the probability distribution of Date $\mathrm{B}$ is not clear in Figure 3, but the OxCal individual calibra-

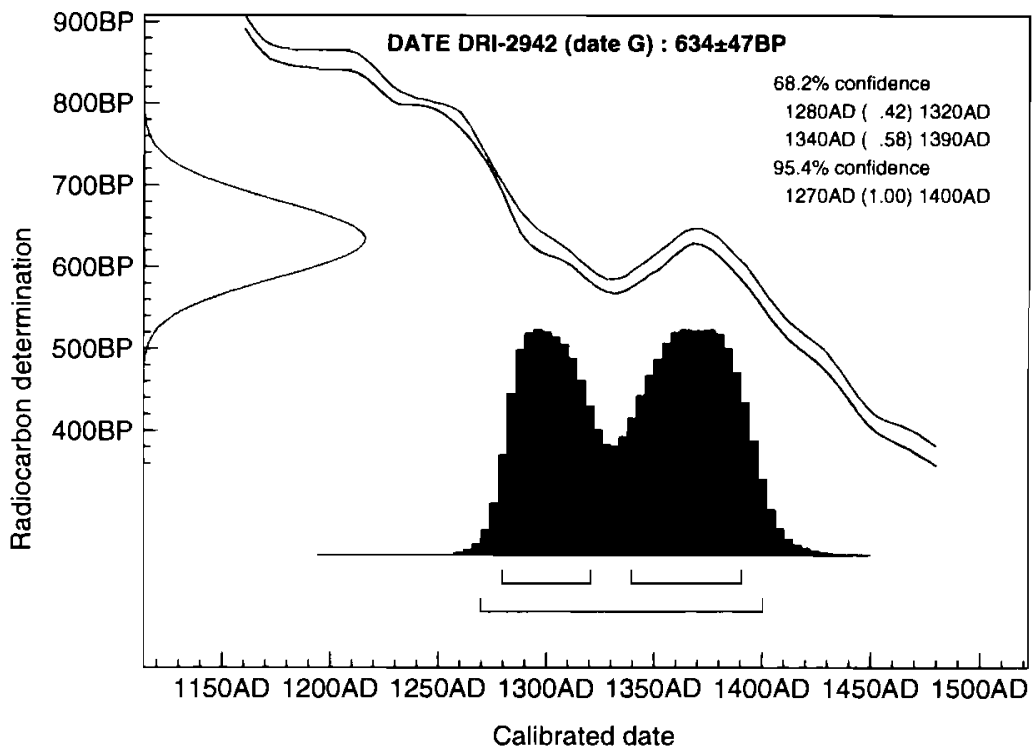

Figure 4. Example of the calibration of a radiocarbon date (Date $G$ ) as presented by the OxCal software. 


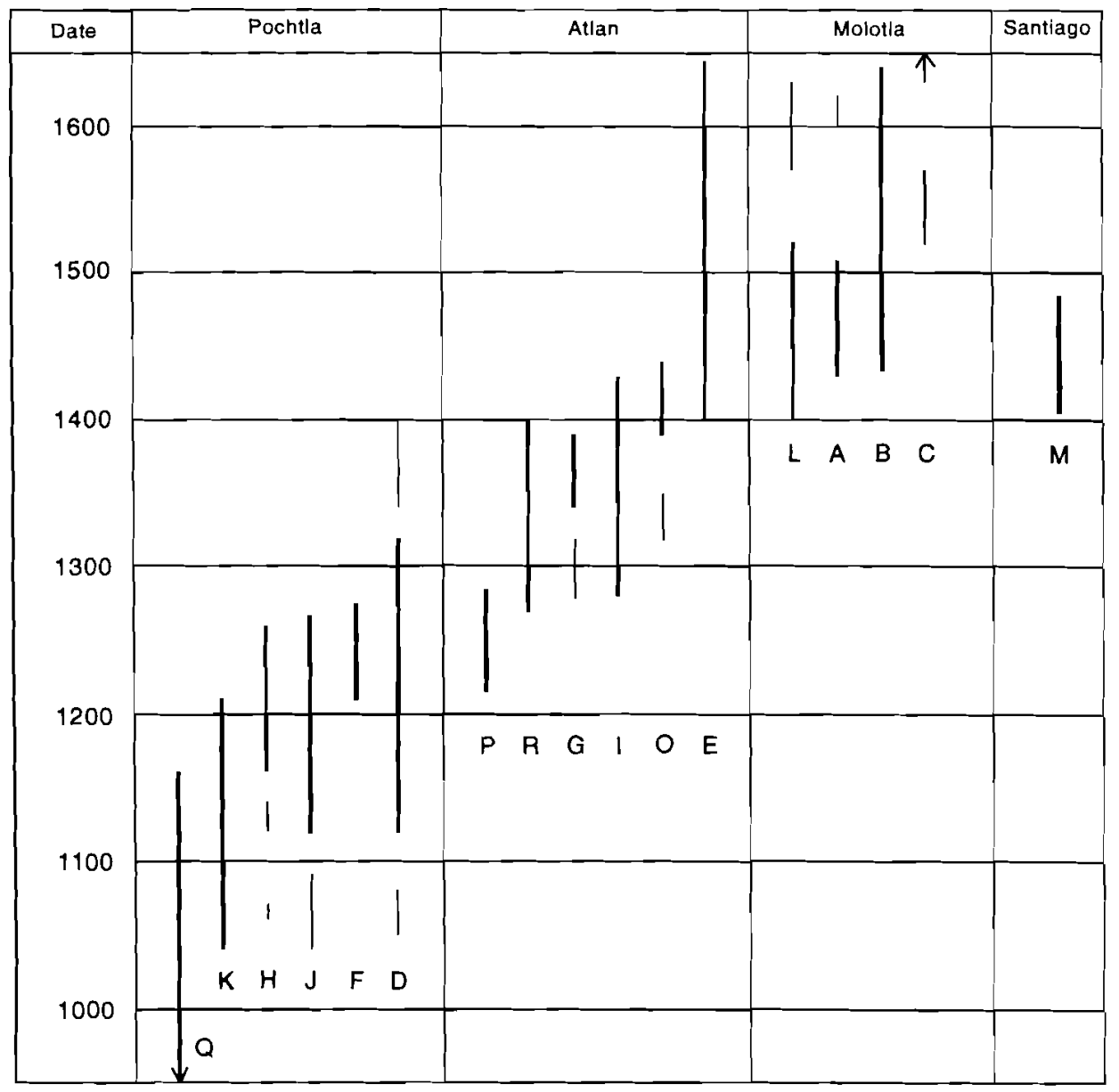

Figure 5. Calibrated radiocarbon dates from Yautepec. This figure portrays the one-sigma ranges for each date. When a date contains more than one date range, the higher-probability range is indicated by the thick lines and lower-probability range[s] by thin lines. Note that the onesigma ranges of Dates $Q$ and $C$ extend beyond the limits of this chart. The data are presented in Table 4. tion plot for this sample shows a mode between about 1450 and 1520). Based upon the time ranges of the dates from Atlan, Molotla, and Santiago contexts, we propose a dating of the Molotla phase between A.D. 1440 and 1540. In this case, we feel that the start date is more reliable than the end date. A better dating and understanding of the end of the Molotla phase and the start of the Santiago phase will have to await additional dates from Santiagophase contexts and further analyses of Santiago deposits and ceramics.

\section{PATTERNS OF CHANGE}

\section{Chronological Classification of the Excavated Contexts}

On the basis of the seriation described in this paper, we are able to allocate most of the middens and architecture from the $1993 \mathrm{ex}$ cavations to the defined chronological phases. Some deposits, however, remain unclassified or only weakly classified. There are still several hundred ceramic collections to classify. Many of these will later be run through the discriminant-function phasing operation, and others will be phased more simply by inspection of their ceramic type composition.

The overall chronological classification of residential contexts is presented in Figure 6. These patterns should be viewed as provisional pending completion of the ceramic analyses and further chronological phasing. There are seven Pochtla-phase midden deposits, none with standing architecture. Several of these contain construction debris (e.g., fragments of lime plaster), probably from houses that were dismantled during later rebuilding activities. It is also possible that the Pochtla-phase houses associated with these middens still exist, but we simply failed to locate them during excavation. The number of classified middens increases in each of the next two phases, although two types of chronological uncertainly remain. Several Late Postclassic middens can not yet be separated into the Atlan or Molotla phases. Two of these are not very dense deposits that yielded small numbers of ceramics from limited test pits (Units 510 and 515). Unit 504 was a very dense midden, but only one ceramic collection from the midden in question has been classified so far. We anticipate that completion of the ceramic analyses will resolve these uncertainties.

The other type of chronological uncertainty concerns occupations in the plow zone. Much of Yautepec was farmed in the Colonial and modern periods, and in many areas the terminal occupations exist solely in the plow zone. It is not yet clear whether these deposits contain material of a single phase or two or more mixed phases. Plow-zone deposits with mixed Late Postclassic and 


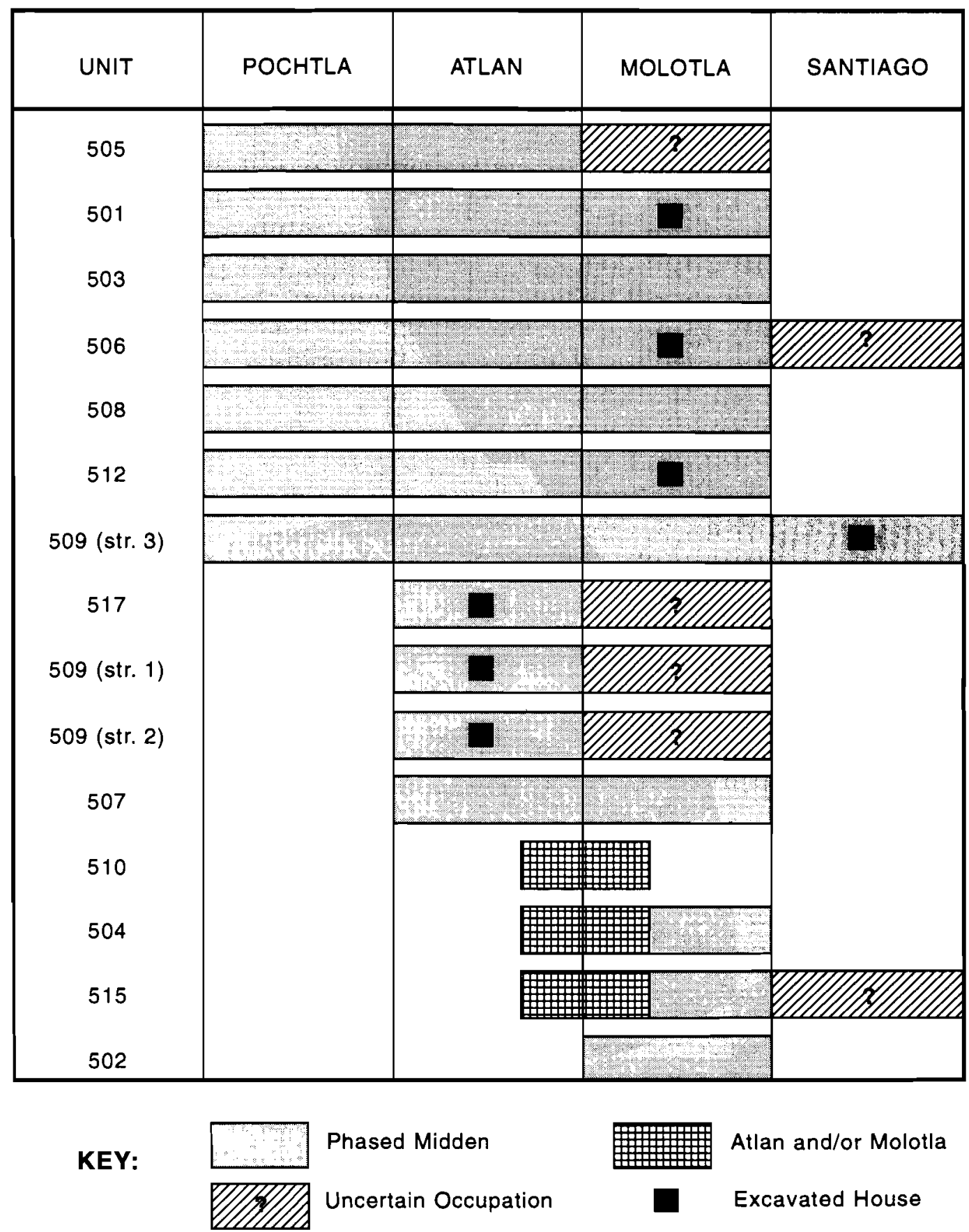

Figure 6. Patterns of occupation through time in the excavated middens at Yautepec. Excavated houses [black squares] are placed with their final phases of occupation here; several were in fact constructed in earlier phases.

Colonial material are especially difficult to distinguish from those with only Colonial material. We hope that continuing research will clarify these deposits. Although Santiago-phase occupations were widespread at Yautepec, only one undisturbed midden, associated with Str. 3 of Unit 509 , pertains to this phase (this deposit yielded the ceramics used to define the Santiago phase).

\section{Ceramic Change}

The 47 ceramic collections used in the cluster analysis were used to construct expected means for each variable for each chronological phase (see Table 1). The expected means by phase are plotted graphically in Figure 7 to show the shifting association of ceramic 


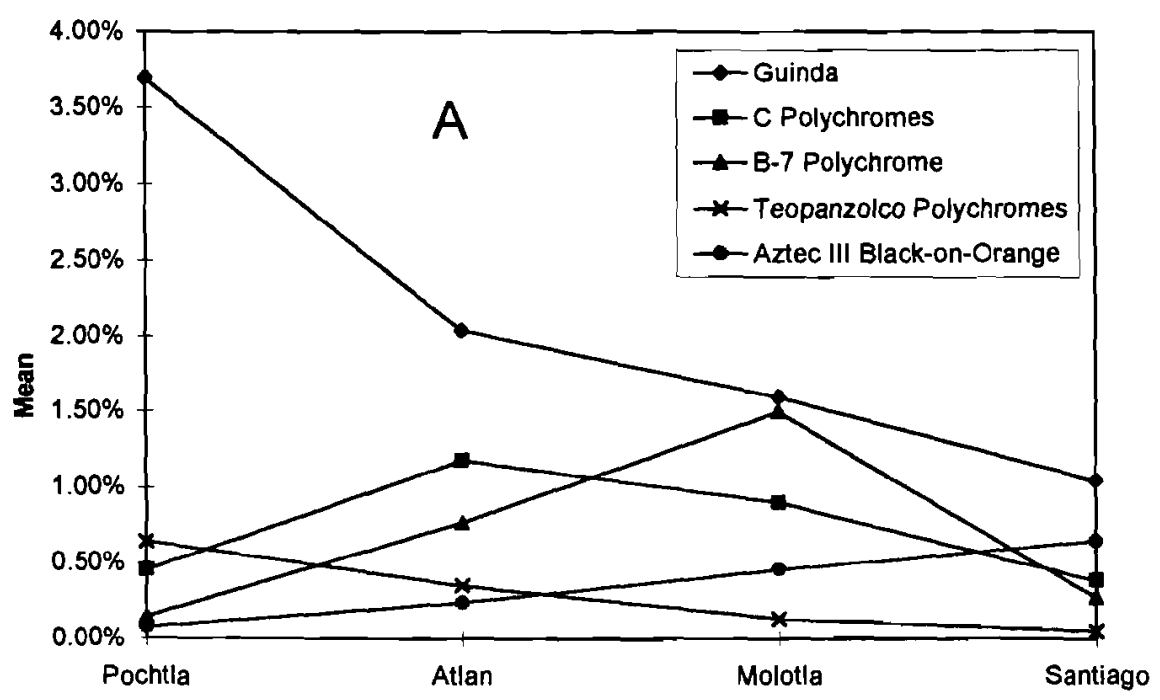

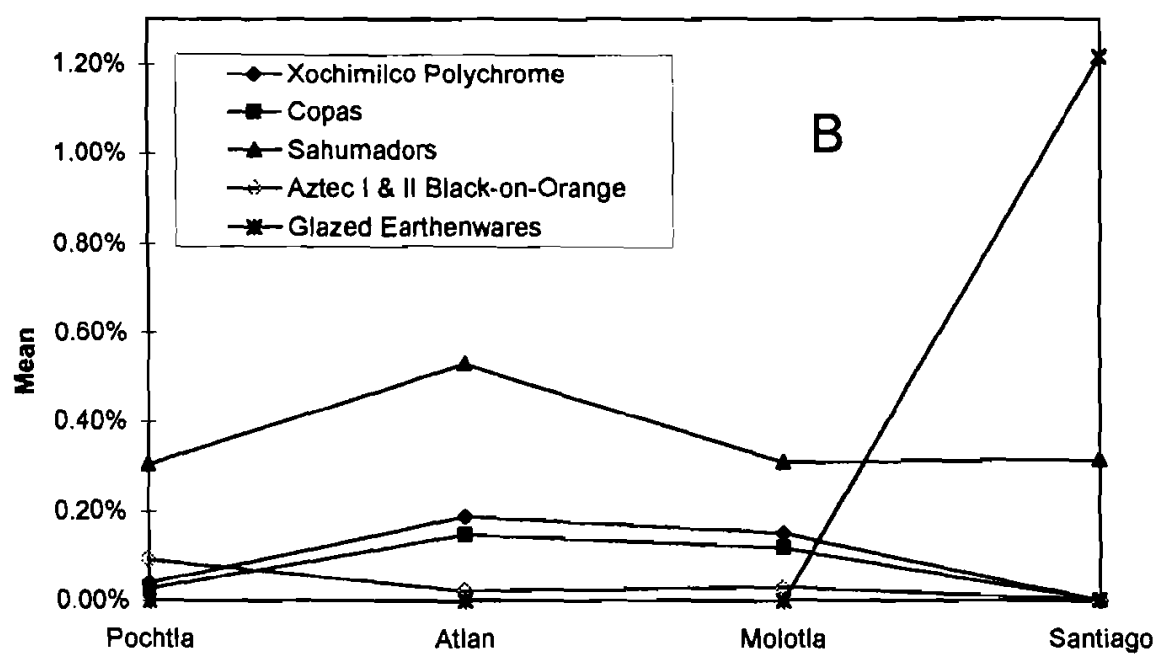

Figure 7. Graphs of ceramic type frequencies by phase. See also Table 1. variables with chronological phases. ${ }^{5}$ We found that the use of six variables-Guinda, C Polychromes, Tlahuica B-7 Polychrome, Teopanzolco polychromes, Aztec III Black-on-orange, and glazed earthenwares-replicated the multidimensional scaling and cluster analysis in most details. The five Postclassic variables among these are the highest frequency variables used in the analysis. The inclusion of the other variables improved the orderings, however.

Guinda (Figure 8), or polished redware, is the highest-frequency variable used in the analysis. The Guinda ceramics used in the se-

s The quantitative data on ceramic change in Figure 7 and Table 1 are presented only to illustrate the seriation, not to provide information on changing social and economic patterns. The latter issues cannot be addressed adequately with the limited data described in this article, and we caution readers against making socioeconomic and functional interpretations of these data. Too few ceramic collections have been classified; those that are available now were selected to aid the chronology, not to adequately sample the excavated remains. Also, the data have not yet been analyzed in a manner designed to address social and functional issues. We plan to quantify ceramics from all well-dated midden contexts using a minimum number of vessels measure, and readers are urged to await the results of that operation before drawing conclusions about such issues as changing patterns of trade, ritual, or other domestic activities and conditions. riation are simple bowls and include a wide range of decorative variants including plain red, black-on-red, black-and-white-onred, and some low-frequency polychrome types (see Hodge and Minc [1991] and Minc [1994] for descriptions and drawings of Guinda). This variable probably includes both imported vessels from outside the Yautepec Valley and locally produced versions (we are currently testing this hypothesis with petrographic and chemical characterization analyses). As in other areas of central Mexico, Guinda is present throughout the Postclassic and Early Colonial periods. At Yautepec, Guinda is present in all phases at greater than $1 \%$ of the total sherds, but peaks in the Pochtla phase and decreases through the Santiago phase. We have identified a number of chronologically significant subtypes of the Guinda class, but these are too rare for inclusion in the statistical analyses. Full descriptions of these and other ceramic types will be presented when the ceramic analyses are completed.

Tlahuica B-7 Polychrome (Figure 9) is the second most abundant variable in the analysis. Tlahuica B-7 Polychrome is a subvariant of the Tlahuica polychromes of Morelos defined by exterior polychrome decoration on bowls with a specific set of decorative zones and designs (see Smith [1983] for descriptions of Tlahuica polychrome types). This is the most abundant of the Tlahuica poly- 

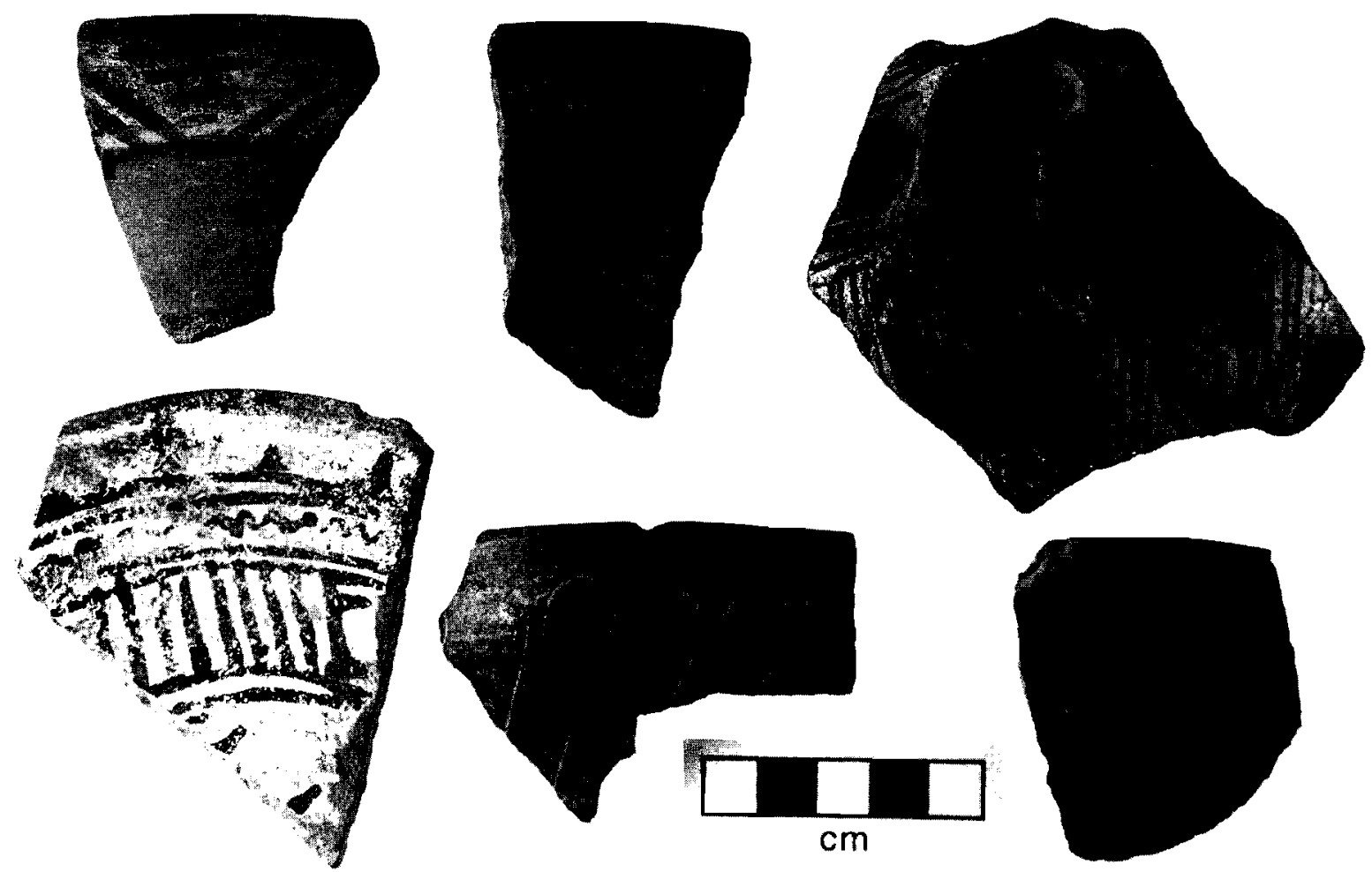

Figure 8. Select chronologically sensitive decorated ceramics from Yautepec: top row, Teopanzolco polychromes (2 sherds), Tiahuica Polychrome jar; bottom row, Tepozteco Bichrome [I sherd]; Guinda [2 sherds].
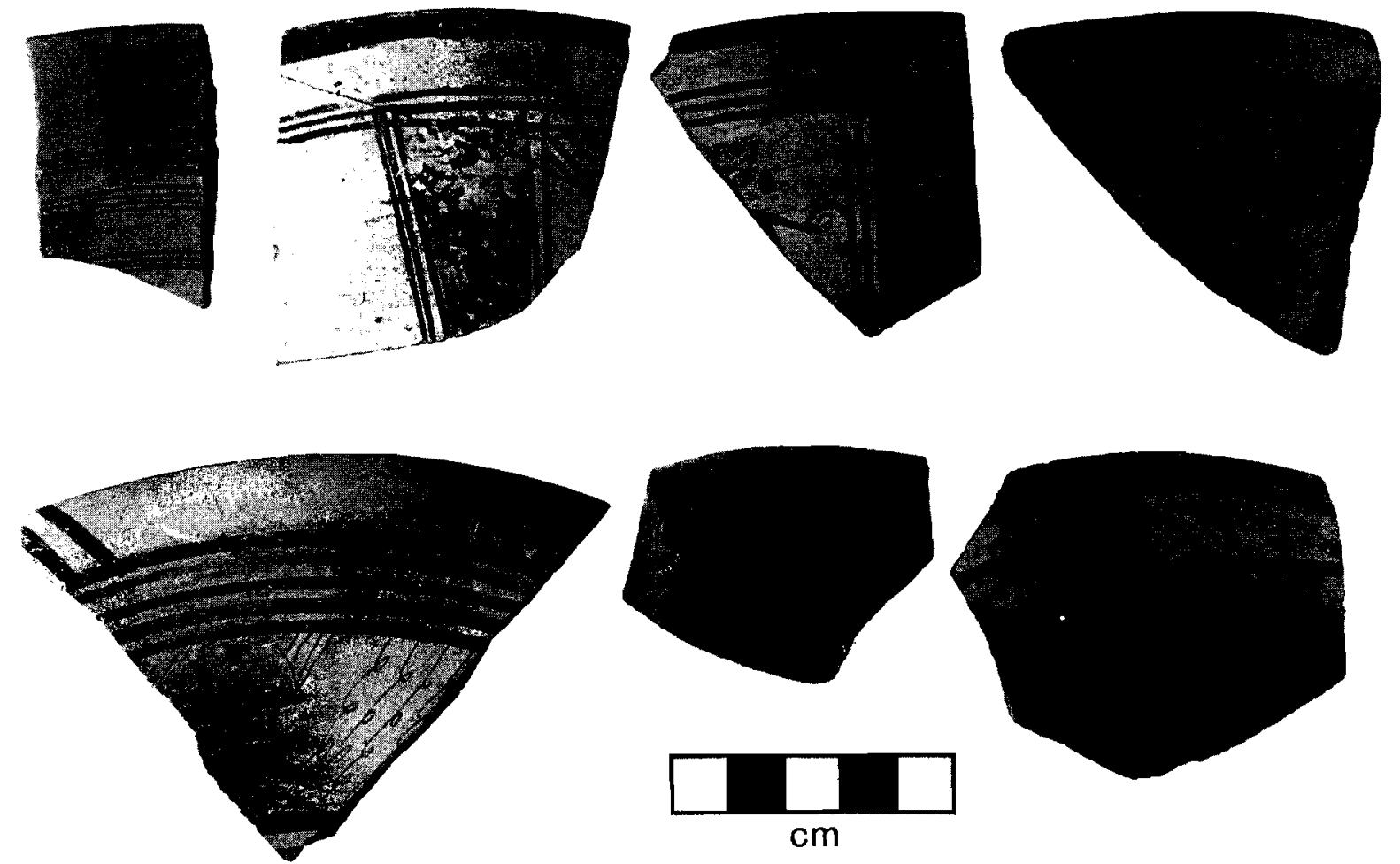

Figure 9. Select chronologically sensitive decorated ceramics from Yautepec: top row, Aztec III Black-on-orange (1 sherd); Tlahuica B-7 Polychrome (3 sherds); bottom row, Aztec III/IV Black-on-orange (1 sherd); Tlahuica C-1 Polychrome (2 sherds). 
chrome types at Yautepec, and we hypothesize that it was manufactured at Yautepec or nearby (this hypothesis will be tested in the future). B-7 Polychrome appears in the Atlan phase, peaks during the Molotla phase, and almost disappears during the Santiago phase.

C Polychrome (see Figure 9) is the third most frequent variable. This is a group of several related types with simple exterior polychrome decoration that Smith has observed in the Yautepec Valley and Norr (1987) has noted in eastern Morelos. C Polychromes are present in low frequencies in the Pochtla and Santiago phases, peak in the Atlan phase, and decrease into the Molotla phase.

Teopanzolco Polychrome (see Figure 8) is the fourth most abundant variable. As defined by Smith, this category consists of several Tlahuica polychrome types from the Cuernavaca area defined by the locations and designs of painted decorations on both the interior and exterior. Teopanzolco polychromes peak in the Pochtla phase and decrease in frequency through the Atlan phase. They are absent in the Molotla and Santiago phases.

Aztec III Black-on-orange (see Figure 9) is the fifth most abundant variable. This category is composed of a broad range of vessel forms, including bowls, dishes, molcajetes, and jars, defined by their distinctive paste and black decoration (Hodge et al. 1993). We think that this variable may include both imported vessels from the Basin of Mexico and local imitations of the Aztec Black-onorange style, a hypothesis that we are currently testing with neutronactivation analysis. Aztec III Black-on-orange is identified as a Late Postclassic marker in most of central Mexico (Smith 1987, 1990). We think that the presence of this type in Pochtla-phase collections is due to either mixture problems or incorrect phasing. It appears in low frequency in the Atlan phase, and increases through the Santiago phase.

Additional variables that are temporally sensitive but of lower frequency include Tepozteco bichromes, Black-on-white jars, Aztec I and II Black-on-orange, Tlahuica Polychrome jars, Xochimilco Polychrome, sahumadors (frying-pan incense burners), and scored incensarios (some of these are illustrated in Figures 8 and 9). Although the frequencies of many of these variables are low, the chronological trends evident in their frequencies indicate that they can be used along with the more abundant classes to aid in the allocation of collections not amenable to quantitative treatment to chronological phases (e.g., excavated collections with low frequencies, grab-bag surface collections, etc.).

\section{Extension of the Chronology to Other Sites}

The trends portrayed in Figure 7 reveal an important characteristic of Postclassic ceramic change at Yautepec: there are no indexfossil types. None of these (or other types) occurred exclusively in a single phase. This situation was also observed in the Postclassic ceramic complexes of western Morelos (Smith 1987; Smith and Doershuk 1991). The temporal changes were quantitative rather than qualitative. Although it is not difficult to define ceramic phases or to assign collections to phases with quantified ceramic collections from midden deposits, the lack of clear chronological markers often makes it difficult to assign other types of collections to the Postclassic phases. Although research on this issue has only begun. we can describe the problem and the approach that we take.

The need to determine the chronological phases of sites outside of Yautepec arises from our 1994 regional survey of the Yautepec Valley (Cascio and Hare 1996: Cascio et al. 1995). Approximately twothirds of the more than 300 sites located in the survey have Postclassic and/or Colonial occupations. We made grab-bag collections (col- lections of diagnostic sherds from large areas) and $2-\times-2-m$ controlled collections at all sites, plus 5- $\times-5$-m controlled collections at many Postclassic sites. In addition, test pits were excavated in Postclassic and Colonial contexts at six sites. The area of the Yautepec Valley covered by the survey was an integrated cultural, economic, and political entity during the Postclassic period, and we expect that the chronological trends defined for Yautepec also characterized other settlements in the valley. It will be a relatively straightforward procedure to determine the phase of excavated ceramic collections with the discriminant-function operation described above. The surface collections pose a greater problem, however.

Surface collections present numerous difficulties for chronology, and for a number of reasons they cannot be allocated to phases by the procedures described above. First, grab-bag collections are heavily biased, and they are not quantifiable in the same manner as excavated collections. Grab-bag surface collections can only be allocated to phases through the presence and absence of chronological markers. Second, quantifiable collections such as our $2-x$ $2-m$ squares yield small quantities of ceramics resulting in the loss of low-frequency types. Third, sherds in surface collections tend to have eroded surfaces (particularly on the clayey soils of the Yautepec Valley), reducing the fineness of classification based on surface treatment and decoration. Fourth, many surface collections include ceramics from more than one chronological phase, due to the operation of diverse formation processes such as plowing at multicomponent sites.

To classify surface collections, we are using a combination of qualitative and quantitative methods. The grab-bag collections tend to include a larger number of low-frequency ceramic types than do the quantifiable collections. These low-frequency types are often chronologically sensitive and can be used to phase the collections on the basis of presence and absence. The quantifiable collections are being used to construct ratios between ceramic types to aid in the differentiation between phases. For example, the ratio of Teopanzolco Polychrome to Aztec III Black-on-orange can monitor change between the three Postclassic phases. To confront the problem of mixed ceramics from multiple phases in the surface collections, we plan to apply the multiple-regression approach of Kohler and Blinman (1987). This procedure quantifies the proportion of the contribution of each phase to the total ceramic collection from potentially mixed contexts. We have only begun to explore these approaches to chronological classification of ceramic collections from outside of Yautepec proper, but we have confidence that the new chronology described above will permit the accurate determination of phases for most of these collections.

\section{CONCLUSIONS}

We have succeeded in producing a more fine-grained ceramic chronology for the Postclassic occupation of Yautepec. The success of this chronology is due to two factors. First, we have a large number of well-documented, stratigraphically related ceramic collections from a variety of domestic contexts at a single site. Similar conditions obtained at the Postclassic sites of Cuexcomate and Capilco in western Morelos, and they contributed to a similar finegrained ceramic chronology (Smith and Doershuk 1991). Second, we have applied a variety of methods and types of data to the problem of chronological refinement. We used ordinary statistical procedures available in most commercial software packages, standard radiocarbon procedures, and basic archaeological principles of stratigraphy, ceramic classification, and cross-ties. This research dem- 
onstrates that chronological refinement is certainly feasible for Postclassic-period sites in central Mexico, and such progress does not require exceptional archaeological contexts, exotic methods, or reliance upon ethnohistoric correlations of dubious validity.

We believe that our emphasis on the definition, ordering, and dating of ceramic phases may be the most efficient approach to chronological refinement in Postclassic central Mexico (and in other areas as well). Our approach is elegantly categorized by George Cowgill's discussion of "phase time" (Cowgill 1996). Our utilization of a large number of ceramic types contrasts with the approach of several papers on the Basin of Mexico (this issue) that emphasize the Aztec orange wares almost exclusively. The accurate dating of the various types of Aztec orange ceramics is a crucial issue for all of central Mexico. Nevertheless, we suggest that greater attention to phases, not types, will produce better chronologies in the Basin of Mexico.

Overemphasis on the Aztec orange wares ignores the potential contributions of many other ceramic types to chronological refinement. Leah Minc (1994), for example, has made notable progress in refining the chronology of Guinda ceramics in the Basin of Mexico, and her advances need to be incorporated into the continuing research on Postclassic chronology described in this issue. Ceramic phases often have durations far shorter than the time spans of individual types. Most types occur in two or three phases at Yautepec and in western Morelos (Smith and Doershuk 1991). For example, Aztec III Black-on-orange imports occur in the Atlan, Molotla, and Santiago phases at Yautepec. If we were to focus on two or three individual types to the exclusion of others, our chronology would not be as fine grained as it is.

This new chronology enables us to study processes of social and economic change at their appropriate temporal scales. Among the issues that will be addressed with this chronology are the nature of urban growth at Yautepec, changing patterns of wealth, status, craft production, and domestic organization of Yautepec households, and the roles of these households in the wider arenas of central Mexican commerce and imperial expansion during the Postclassic and Early Colonial periods. This sequence lays the foundation for continuing chronological research in the Yautepec area. The authors and other personnel associated with the Yautepec project are currently working on issues such as the detection of change within the phases defined here, the extension of these phases to other sites located in the 1994 survey of the Yautepec Valley, the refinement of the Colonial-period sequence, the dating of the Epecapa (Early Postclassic) phase, and the refinement of chronologies for the Formative and Classic periods. Chronology does not have to be seen as a chore to be gotten out of the way before we can address interesting topics. Rather, chronological research should be an ongoing component of archaeological projects so that we can match the resolution of our phases to the diachronic processes we wish to study.

\section{RESUMEN}

Describimos la construcción de una nueva cronología arqueológica para el período postclásico en Yautepec, Morelos. Primero, aplicamos un análisis de racimo a las frecuencias de tipos cerámicos procedentes de contextos excavados, buscando con ello identificar relaciones entre los grupos de colecciones de cerámica. La clasificación se extiende luego a varios cientos de otras colecciones mediante la aplicación de análisis de funciones discriminantes. Por último, los grupos resultantes son contrastados exito- samente con la estratigrafía y con fechados de radiocarbono, definiendo entonces las fases cronológicas. Utilizamos fechados de radiocarbono para asignar fechas caléndricas a dichas fases. La nueva cronología define una fase de la época postclásica media (fase Pochtla), dos fases del postclásico tardío (fases Atlán y Molotla), y una fase de la época colonial temprana (fase Santiago). También discutimos la extensión de esta cronología a otros sitios en el valle de Yautepec.

\section{ACKNOWLEDGMENTS}

Excavations at Yautepec were funded by the National Science Foundation, the National Endowment for the Humanities, the Heinz Charitable Trust, and the State University of New York at Albany. We thank Hortensia de Vega Nova and Norberto González Crespo of the Instituto Nacional de Antropología e Historia for their support and advice, and the people of Yautepec for their interest and support. We thank Herbert Haas of the Radiocarbon Laboratory, Desert Research Institute, for his expert processing

\section{REFERENCES}

Aldenderfer, Mark S., and Roger K. Blashfield

1984 Cluster Analysis. Sage Publications, Beverly Hills, CA.

Berdan, Frances F., Richard E. Blanton. Elizabeth H. Boone, Mary G. Hodge, Michael E. Smith. and Emily Umberger

1996 Aztec Imperial Strategies. Dumbarton Oaks Research Library and Collection, Washington, DC.

Braudel, Fernand

1980 On History. University of Chicago Press, Chicago.

Cascio, Lisa M., and Timothy S. Hare

1996 Settlement Patterns, Demography, and Sociopolitical Change in the Yautepec Valley, Morelos. Paper presented at the 61 st Annual Meeting of the Society for American Archaeology, New Orleans.

Cascio. Lisa M., Timothy S. Hare, and Michael E. Smith

1995 Archaeological Survey of the Yautepec Valley, Morelos, Mexico. Paper Presented at the 60th Annual Meeting of the Society for American Archaeology, Minneapolis. of the carbon samples and his help with calibration. We also thank Silvia Salgado for improving the Spanish abstract. Conversations and communications with the authors of the other papers in this issue have aided our thinking about Postclassic chronology. The comments of George Cowgill, Robert Dunnell, and Geoffrey McCafferty on an earlier draft of this paper have helped us improve the precision and clarity of the presentation. Figures 1,5 , and 6 were prepared by Michael E. Smith.

Cowgill, George L.

1972 Models, Methods. and Techniques for Seriation. In Models in Archaeology, edited by David L. Clarke, pp. 381-424. Methuen, London. 1996 Discussion. Ancient Mesoamerica 7:325-331.

Curet, L. Antonio, Barbara L. Stark, and Sergio Vásquez Z.

1994 Postclassic Changes in Veracruz, Mexico. Ancient Mesoamerica 5:13-32.

Drennan, Robert D.

1976a A Refinement of Chronological Seriation Using Nonmetric Multidimensional Scaling. American Antiquity 41:290-302.

1976b Fábrica San José and Middle Formative Society in the Valley of Oaxaca. Memoirs No. 8. Museum of Anthropology, University of Michigan, Ann Arbor.

Duff, Andrew I.

1996 Ceramic Micro-Seriation: Types or Attributes? American Antiquity 61:89-101. 
Dunnell, Robert C.

1970 Seriation Method and Its Evaluation. American Antiquity 35:305319.

Ford, James A

1962 A Quantitative Method for Deriving Cultural Chronology. Technical Manual No. I. Pan American Union, Washington, DC.

Hinz, Eike, Marie Heimann-Koenen, and Claudine Hartau 1983 Aztekischer Zensus: Zur Indianischen Wirtschaft und Gesellschaft Im Marquesado Um 1540. Verlag für Ethnologie, Hanover.

Hodge, Mary G., and Leah D. Minc

1990 The Spatial Patterning of Aztec Ceramics: Implications for Prehispanic Exchange Systems in the Valley of Mexico. Journal of Field Archaeology 17:415-437.

1991 Aztec-Period Ceramic Distribution and Exchange Systems. Submitted to the National Science Foundation. Washington. DC

Hodge, Mary, and Michael E. Smith (editors)

1994 Economies and Polities in the Aztec Realm. Institute for Mesoamerican Studies, Albany.

Hodge, Mary G., Hector Neff, M. James Blackman, and Leah D. Minc

1993 Black-on-Orange Ceramic Production in the Aztec Empire's Heartland. Latin American Antiquity 4:130-157.

Johnson, Leroy

1972 Introduction to Imaginary Models for Archaeological Scaling and Clustering. In Models in Archaeology, edited by David L. Clarke, pp. 309-379. Methuen, London.

Kohler, Timothy A., and Eric Blinman

1987 Solving Mixture Problems in Archaeology: Analysis of Ceramic Materials for Dating and Demographic Reconstruction. Journal of Anthropological Archaeology 6:1-28.

Kruskal, Joseph B., and Myron Wish

1978 Multidimensional Scaling. Sage Publications, Beverly Hills, CA.

LeBlanc, Stephen A.

1975 Micro-Seriation: A Method for Fine Chronological Differentiation. American Antiquity 40:22-38.

Lockhart, James

1992 The Nahuas After the Conquest: A Social and Cultural Histon of the Indians of Central Mexico, Sixteenth Through Eighteenth Centuries. Stanford University Press, Stanford, CA.

Marquardt, William $\mathrm{H}$.

1978 Advances in Archaeological Seriation. In Advances in Archaeological Method and Theory, vol. 1, edited by Michael B. Schiffer pp. 266-314. Academic Press, New York.

Martin, Cheryl E.

1985 Rural Society in Colonial Morelos. University of New Mexico Press, Albuquerque.

Michels, Joseph W.

1973 Dating Methods in Archaeology. Academic Press, New York.

Minc, Leah

1994 Political Economy and Market Economy Under Aztec Rule: A Regional Perspective Based on Decorated Ceramic Production and Distribution Systems in the Valley of Mexico. Ph.D. dissertation, University of Michigan. University Microfilms, Ann Arbor.

Nichols, Deborah L., and Thomas H. Charlton

1996 The Postclassic Occupation at Otumba: A Chronological Assessment. Ancient Mesoamerica 7:231-244.

Norr, Lynette

1987 Postclassic Artifacts from Tetla. In Ancient Chalcatzingo, edited by David C. Grove, pp. 525--546. University of Texas Press, Austin

Norusis, Marija J.

1992a SPSS/PC + Professional Statistics Version 5.0. SPSS, Chicago. 1992b SPSS/PC + Advanced Statistics Version 5.0. SPSS, Chicago

Parsons, Jeffrey $R$.

1966 The Aztec Ceramic Sequence in the Teotihuacan Valley, Mexico. 2 vols. Ph.D. dissertation, University of Michigan. University Microfilms, Ann Arbor.

Parsons, Jeffrey R., Elizabeth Brumfiel, and Mary Hodge

1996 Developmental Implications of Earlier Dates for Early Aztec in the Basin of Mexico. Ancient Mesoamerica 7:217-230.

Plog, Fred $\mathrm{T}$

1974 The Study of Prehistoric Change. Academic Press, New York.

Ramsey, Christopher Bronk

1995 Oxcal Program v. 2.18. Oxford Radiocarbon Accelerator Unit. Oxford.

Robinson, W.S.

1951 A Method for Chronologically Ordering Archaeological Deposits. American Antiquity 16:239-301.
Rouse, Irving

1967 Seriation in Archaeology. In American Historical Anthropology: Essays in Honor of Leslie Spier, edited by Carroll L. Riley and Walter W. Taylor, pp. 153-195. Southern Illinois University Press, Carbondale.

Rowe, John $\mathrm{H}$

1959 Archaeological Dating and Cultural Process. Southwestern Journal of Anthropology 15:317-324.

Sackett, James

1977 The Meaning of Style in Archaeology: A General Model. American Antiquity 42:369-380.

Sanders, William T., Jeffrey R. Parsons, and Robert S. Santley

1979 The Basin of Mexico: Ecological Processes in the Evolution of a Civilization. Academic Press, New York.

Santley, Robert S., and Kenneth G. Hirth (editors)

1993 Prehispanic Domestic Units in Western Mesoamerica: Studies of the Household, Compound, and Residence. CRC Press, Boca Raton, FL.

Schiffer, Michael B.

1987 Formation Processes of the Archaeological Record. University of New Mexico Press, Albuquerque.

Smith, Michael E.

1983 Postclassic Culture Change in Western Morelos, Mexico: The Development and Correlation of Archaeological and Ethnohistorical Chronologies. Unpublished Ph.D. dissertation, Department of Anthropology, University of Illinois, Urbana.

1987 The Expansion of the Aztec Empire: A Case Study in the Correlation of Diachronic Archaeological and Ethnohistorical Data. American Antiquity 52:37-54.

1990 Long-Distance Trade Under the Aztec Empire: The Archaeological Evidence. Ancient Mesoamerica 1:153-169.

1992a Braudel's Temporal Rhythms and Chronology Theory in Archaeology. In Annales, Archaeology, and Ethnohistory, edited by A. Bernard Knapp, pp. 23-34. Cambridge University Press, New York.

1992b Excavations and Architecture. Archaeological Research at AztecPeriod Rural Sites in Morelos, Mexico, vol. 1. Monographs in Latin American Archaeology No. 4. University of Pittsburgh, Pittsburgh.

1994 Excavaciones de casas postclásicas del centro urbano de Yautepec, Morelos: Informe técnico parcial. Report submitted to the Instituto Nacional de Antropología e Historia, Mexico City.

1996 The Aztecs. Blackwell Publishers, Oxford.

Smith, Michael E., and John F. Doershuk

1991 Late Postclassic Chronology in Western Morelos, Mexico. Latin American Antiquity 2:291-310.

Smith, Michael E.. Cynthia Heath-Smith, Ronald Kohler, Joan Odess, Sharon Spanogle, and Timothy Sullivan

1994 The Size of the Aztec City of Yautepec: Urban Survey in Central Mexico. Ancient Mesoamerica 5:1-11.

Smith, Michael E.. Cynthia Heath-Smith, and Lisa M. Cascio

1996 Aztec Urban Houses in Yautepec, Morelos, Mexico. Manuscript on file, Department of Anthropology, State University of New York, Albany.

Spaulding, Albert C

1978 Artifact Classes, Association, and Seriation. In Archaeological Essays in Honor of Irving B. Rouse, edited by R. C. Dunnell and E. S. Hall, pp. 27-40. Mouton, The Hague.

Stuiver, Minze, and Bernd Becker

1986 High-Precision Decadal Calibration of the Radiocarbon Time Scale, AD 1950-2500 BC. Radiocarbon 28:863-910.

Stuiver. Minze, and Renee S. Kra (editors)

1986 Calibration Issue: Proceedings of the Twelfth International $R a$ diocarbon Conference-Tronheim, Norway. Radiocarbon 28(2B).

Stuiver, Minze, Austin Long and Renee S. Kra (editors)

1993 Calibration Issue. Radiocarbon 35(1).

Tatsuoka, Maurice M.

1970 Discriminant Analysis: The Study of Group Differences. Institute for Personality and Ability Testing, Champaign. IL.

Waterbolk, H.T.

1983 Ten Guidelines for the Archaeological Interpretation of Radiocarbon Dates. In Proceedings of the First International Symposium. ${ }^{14} \mathrm{C}$ and Archaeology (Groningen, 1981), edited by W.G. Mook and H.T. Waterbolk, pp. 57-70. Council of Europe. Stasbourg.

Wilkinson, Leland

1990 SYSTAT: The System for Statistics. SYSTAT, Evanston, IL. 